\title{
Synthesis, Biological Evaluation and Utility of Fluorescent Ligands Targeting the $\mu$-Opioid Receptor
}

\author{
Luke S. Schembri, ${ }^{\dagger}$ Leigh A. Stoddart,${ }^{\S}$ Stephen J. Briddon, ${ }^{\S}$ Barrie Kellam,,$*$ \\ Meritxell Canals,,$*$ Bim Graham, ${ }^{*}{ }^{\dagger}$ and Peter J. Scammells $*,+$
}

${ }^{\dagger}$ Medicinal Chemistry and ${ }^{\star}$ Drug Discovery Biology, Monash Institute of Pharmaceutical Sciences, Monash University, Parkville, Victoria, 3052, Australia.

$\S$ Cell Signaling Research Group, School of Life Sciences, Queen’s Medical Centre, University of Nottingham, Nottingham NG7 2UH, UK

* School of Pharmacy, Centre for Biomolecular Sciences, University of Nottingham, Nottingham NG7 2RD, UK

KEYWORDS: opioid receptor, fluorescent imaging, opioid antagonist, fluorescent ligand 
ABSTRACT: Fluorescently-labeled ligands are useful pharmacological research tools for studying receptor localization, trafficking and signaling processes via fluorescence imaging. They are also employed in fluorescent binding assays. This study is centered on the design, synthesis and pharmacological evaluation of fluorescent probes for the opioid receptors, for which relatively few non-peptidic fluorescent probes currently exist. The known $\mu$-opioid receptor (MOR) partial agonist, buprenorphine, was structurally elaborated to include an amidoalkylamine linker moiety that was coupled with a range of fluorophores to afford new fluorescent probes. All compounds proved to be selective MOR antagonists. Confocal fluorescence microscopy studies revealed that the probe incorporating a sulfonated cyanine-5 fluorophore (3) was the most appropriate for imaging studies. This ligand was subsequently employed in an automated fluorescence-based competition binding assay, allowing the $\mathrm{p} K_{\mathrm{i}}$ values of several well-known opioid ligands to be determined. Thus, this new probe will prove useful in future studies of MOR receptor pharmacology. 


\section{- INTRODUCTION}

Opiates, such as morphine, are one of the most efficacious classes of analgesics in use today for the treatment of acute and chronic pain. They elicit their effects by binding to the three "classical" opioid receptors (ORs) - the $\mu, \kappa$ and $\delta$ receptors (MOR, KOR and DOR) - and some to the more recently discovered nociceptin receptor (NOR), ${ }^{1,2}$ all of which are classified as class A, peptidebinding, $\gamma$-subtype G protein-coupled receptors (GPCRs). ${ }^{3}$ The four ORs couple to the same major intracellular signaling pathways, interacting with $G$ proteins of the $G_{i / o}$ family. Upon GPCR activation, the $\beta / \gamma$ subunit of the heterotrimeric $G$ protein is released and acts to inhibit voltage-gated calcium channels and activate inwardly-rectifying potassium channels. This in turn leads to cell hyperpolarization and inhibition of neurotransmitter release, thus inhibiting neuronal signaling. ${ }^{4}$ Additionally, the $\alpha$ subunit of the G protein inhibits adenylyl cyclase and hence decreases intracellular cyclic adenosine monophosphate (cAMP) production. ${ }^{5,6}$

Notwithstanding their effectiveness as analgesics, opiates suffer from a myriad of dose-limiting side-effects, including constipation, hallucinations, sedation, respiratory depression and, perhaps most significantly, tolerance and physical dependence. ${ }^{7}$ In order to develop opiates with an improved sideeffect profile, more fundamental biological research is needed to determine how such adverse effects arise. Additionally, more structure-activity relationships (SARs) must be established so as to be able to enhance or maintain potency whilst reducing or eliminating undesirable side-effects.

Fluorescently-labeled GPCR ligands are useful for the above endeavors as they can be used in an array of pharmacological experiments, most notably, real-time monitoring of cellular processes such as receptor trafficking and ligand binding. ${ }^{8-13}$ Due to their high sensitivity, such probes can generate meaningful pharmacological data from a few cells (such as a biopsy) and thus may be useful in determining pharmacological differences between diseased and healthy tissue. Moreover, they may be used to determine the binding affinity of drug candidates via fluorescence resonance energy transfer 
(FRET)-based assays or assays involving displacement of a probe containing an environmentallysensitive fluorophore. ${ }^{14}$

Traditionally, receptor binding assays have been performed using competitive radioligands, with the binding affinity of a drug candidate determined from its ability to displace a high-affinity radiolabeled ligand. Such experiments require a large population of cells, whereas information can be obtained from just a few cells, or even a single cell, using fluorescent probe-based experiments. ${ }^{15}$ Fluorescent probes are generally easier to handle, provide high sensitivity, and can be used to visually differentiate between specific and nonspecific binding if used in conjunction with fluorescently labeled receptors. ${ }^{16}$ Moreover, from a safety point of view, the waste generated from the use of such probes is far less dangerous to the environment and the user than that produced by radiometric assays, ${ }^{17}$ making them more amenable to high-throughput screening (HTS) applications. A fluorescent ligand must, however, be carefully designed to ensure that it retains (or improves upon) the pharmacological properties of the ligand upon which it is based. Due consideration must be given to not only the choice of ligand, but also linker length, linker chemistry, site of linker attachment, as well as the fluorophore. ${ }^{14,15}$

Relatively few fluorescent probes have been developed thus far for the ORs. Fluorescentlylabeled enkephalin peptides (endogenous OR ligands) were the first such compounds to be reported. ${ }^{18-}$ 23. Artamangkul, Macey and coworkers appended the Alexa 488 and 594 fluorophores to dermorphin and employed these conjugates in various imaging and receptor trafficking studies. ${ }^{10,11,13}$ Most recently, Ghosh and co-workers decorated fluorescent quantum dots with multiple copies of a Deltorphin-II analog peptide, permitting single-molecule imaging of the human DOR expressed in CHO cells. ${ }^{24}$ In terms of non-peptidic designs, Kolb et al. ${ }^{25}$ have labeled oxymorphone, naltrexone and naloxone at the C-6 position with fluorescein (and rhodamine-B in the case of naloxone). Although the resulting probes broadly retain the OR-mediated activities of their parent compounds, their receptor 
binding affinities were significantly diminished, and they were not employed for fluorescent visualization/detection of ORs. ${ }^{25}$ Medzihradsky, Emmerson and co-workers have attached the environmentally-sensitive (solvatochromic) fluorophore, 7-nitrobenzo-2-oxa-1,3-diazole (NBD), to a tetrahydrothebaine derivative, ${ }^{26}$ and both NBD and the 4,4-difluoro-4-bora-3a,4a-diaza-s-indacene (BODIPY) fluorophore to $\beta$-naltrexamine. ${ }^{26,27}$ The NBD-bearing compounds lacked significant selectivity, and the absorbance and emission wavelengths of the NBD and green-emitting BODIPY fluorophores are not optimal for biological imaging applications. The tetrahydrothebaine derivative was also too hydrophobic, leading to non-specific binding to cellular membranes. ${ }^{26}$ The BODIPY derivatives exhibited MOR affinities in the nanomolar-to-sub-nanomolar range, with one showing a selectivity ratio of $>40$ for MOR over DOR and KOR. Portoghese and co-workers have reported the development of fluorescein-labeled KOR-selective arylacetamide agonists, ${ }^{28}$ however fluorescein suffers from a high photo-bleaching rate $^{29}$ and its photophysical properties are generally not optimal for receptor imaging studies.

It is clear from the above that there still remains considerable scope for the development of fluorescent OR probes of practical utility, i.e., probes possessing both binding and photophysical properties suitable for imaging of OR localization and trafficking, and/or fluorescent-based screening assays. Herein, we present the synthesis, biological evaluation and application of a series of fluorescent OR antagonists with improved MOR selectivity (Figure 1), based on the high-affinity opioid, buprenorphine. The latter is indicated in Europe for the relief of pain, whilst globally it is used in the treatment of opiate abuse. It is a partial MOR and NOR agonist, KOR and DOR antagonist, is more potent than morphine, and has less unwanted side-effects owing to its ceiling effect on tolerance and respiratory depression. ${ }^{30}$ It provides an attractive scaffold for generating fluorescent probes for ORs because of its strong binding affinity $\left[\mathrm{p} K_{\mathrm{i}}(\mathrm{MOR})=8.8\right]^{31}$ and the possibility to couple it to certain chemical moieties, such as a spacer or linker. Indeed, some related compounds already have alkyl 
chains appended at the C-20 position and this has resulted in extremely high affinity ligands. ${ }^{32}$ Inspired by this work, probes were designed featuring four different fluorophores: sulfonated cyanine-5 (sulfoCy5), boron dipyrromethene difluoride (BODIPY $\left.{ }^{\mathrm{TM}}\right)$ 630/650, 4-((6-methoxy-1,2,4,5-tetrazin-3yl)oxy)butanoic acid (tetrazine) and 3-(6-amino-1,3-dioxo-1 $H$-benzo[de]isoquinolin-2(3H)yl)propanoic acid (naphthalimide). Through measurement of their respective receptor pharmacology, alongside fluorescence confocal microscopy, this study clearly demonstrates the suitability of the sulfoCy5-bearing fluorescent ligand, in particular, for receptor localization studies, as well as in vitro binding assays. This probe possesses the advantage of exhibiting increased fluorescence in the MORbound state, obviating the need for a wash step included in many competitive binding assays.
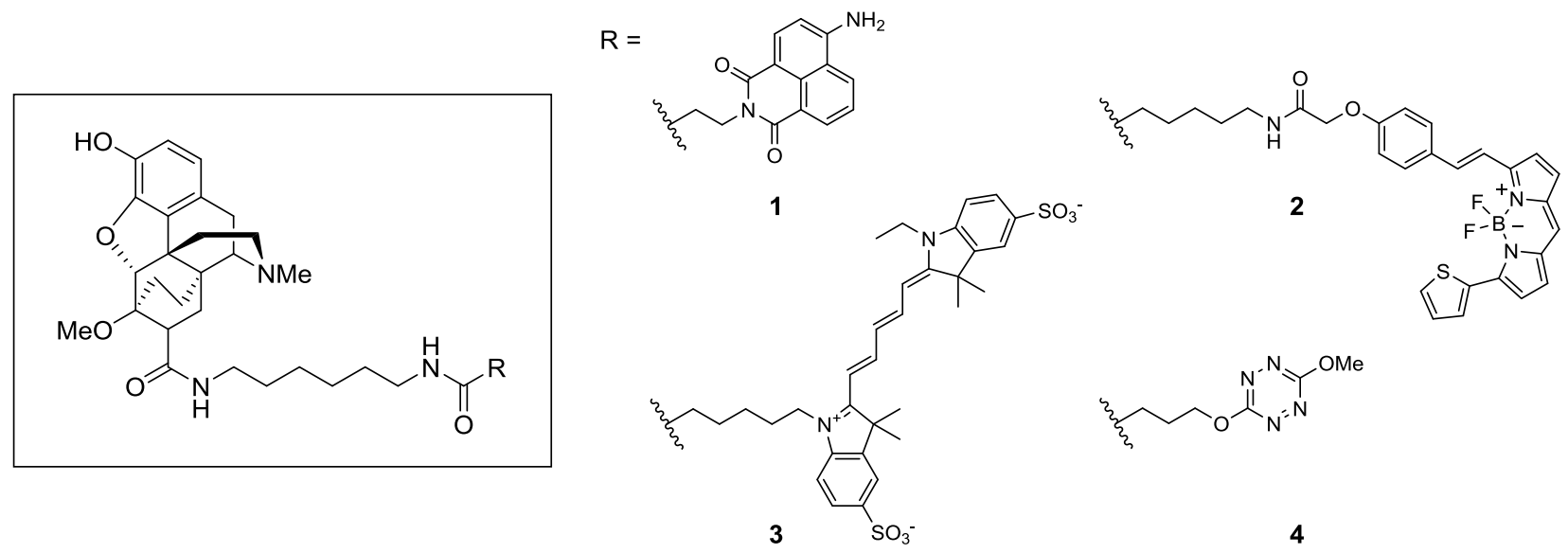

Figure 1. Structures of fluorescent OR ligands synthesized in this study. 


\section{- RESULTS AND DISCUSSION}

Fluorescent ligand design and synthesis. A range of ligand design options were considered in which the linker and fluorophore could be attached to different positions of a morphinan core. Linking from the tertiary amine seemed chemically feasible (e.g. via $N$-demethylation and alkylation), however the OR crystal structures ${ }^{1,7-9}$ suggested that this amine is buried deep within the active site and would therefore have limited tolerance to groups appended at this position. Some substitutions at this position can convert agonists to antagonists, as evidenced by naltrexone. Linking from the 3-position of the phenol moiety was another potential strategy. However, even simple methylation at this position (codeine) reduces binding affinity by approximately 200 -fold. ${ }^{33}$ A more interesting possibility for linker attachment was the 7-position of the morphinan scaffold, via a Diels-Alder reaction, since this could lead to an increase in affinity, as demonstrated by ligands such as etorphine and buprenorphine. ${ }^{34}$ Previous work conducted on the development of fluorescently labeled OR ligands ${ }^{25-28}$ as well as bivalent ligands ${ }^{35-44}$ indicates that the C-ring of the morphinan scaffold (which incorporates the 6- and 7-positions) is generally reasonably tolerant of substitution. With these factors in mind, the synthesis and biological evaluation of three different congeners (Figure 2) featuring a linker attached via the 7position were pursued. In two of these structures $(\mathbf{9}$ and 11) the linker was attached via a Diels-Alder reaction involving the C-ring diene of oripavine and methyl acrylate. Subsequent saponification and amide coupling incorporated the full linker unit (amide congeners). The third congener was derived from the Diels-Alder reaction of oripavine with a fully formed linker unit that possessed a terminal $\mathrm{N}$ substituted maleimide group (imide congener). Literature precedence suggests that conjugation of a maleimide group retains affinity when connected in this position, and alkyl chains are also tolerated..$^{45,46}$ 


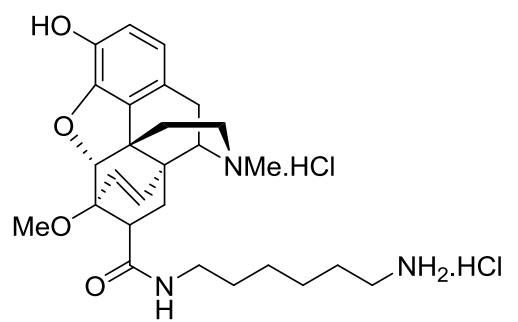

9

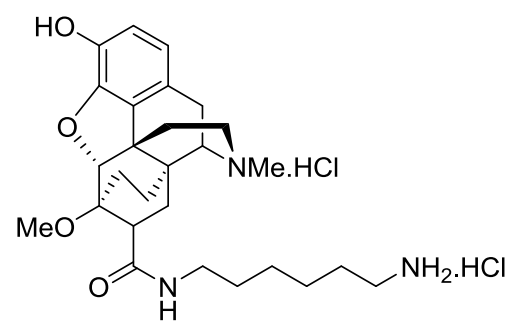

11

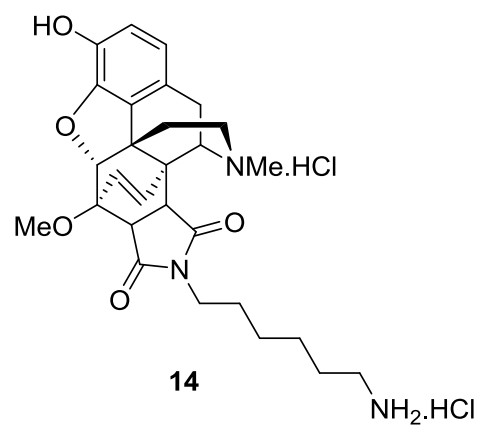

Figure 2. Structures of buprenorphine-like congeners prepared in this study.

Amide congeners. Scheme 1 details the synthetic pathway used to access the amide derivatives, with oripavine as the starting molecule. Following protection of phenol $\mathbf{5}$ to its corresponding tertbutyldimethylsilyl (TBS) ether (6), a Diels-Alder reaction between the latter and methyl acrylate, afforded ester $7 .^{47}$ Compared to dienophiles such as methyl vinyl ketone, the ester presents a weaker electron-withdrawing group compared to the ketone, therefore requiring more forcing conditions to achieve complete conversion to the Diels-Alder product. This was achieved through irradiating the sample for three hours at $130{ }^{\circ} \mathrm{C}$ in a microwave in neat methyl acrylate. Compound 7 was isolated in good yield (69\%) following recrystallization from minimal hot methanol, which was necessary to remove a small amount of the 8-regioisomer byproduct. 
Scheme 1. Synthesis of amide congeners. ${ }^{a}$
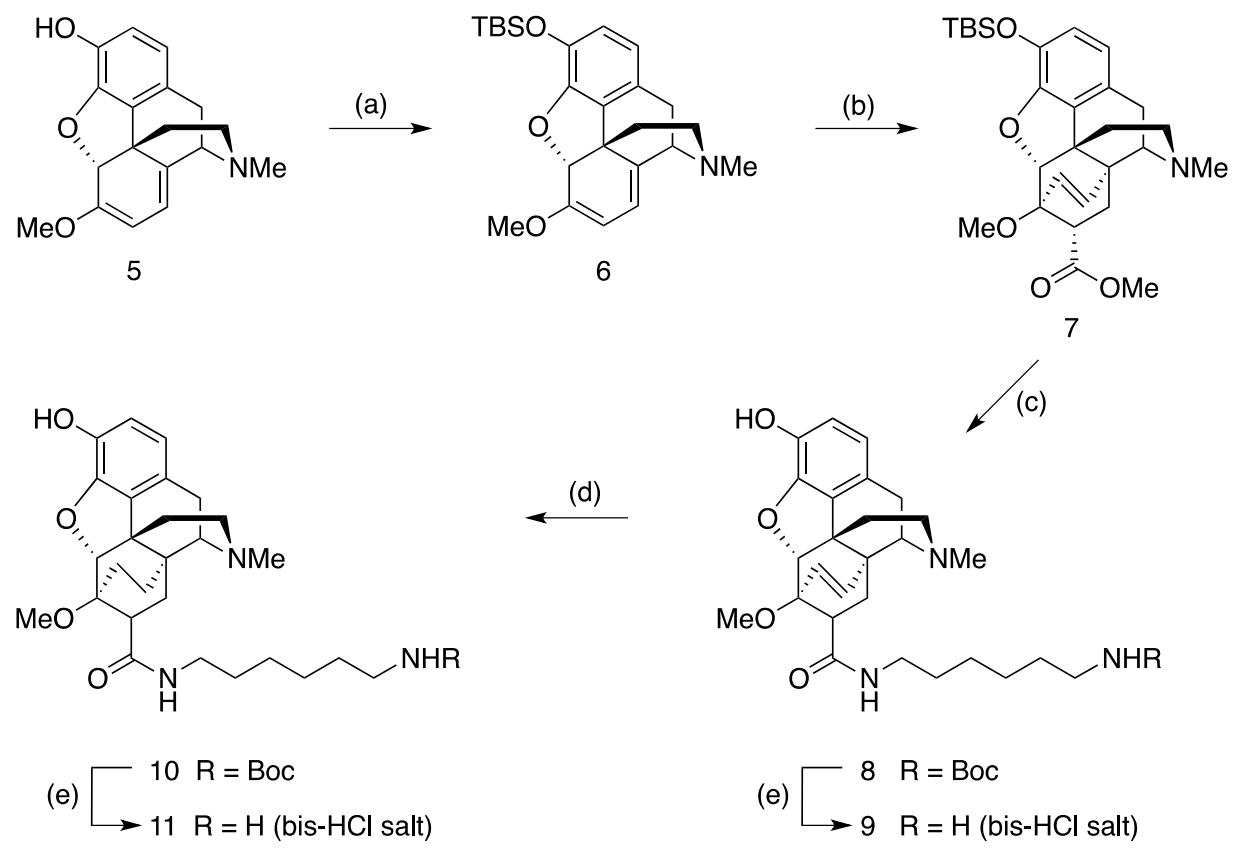

${ }^{a}$ Reagents and conditions: (a) TBSCl, imidazole, DMF, RT, 1 min, 94\%; (b) methyl acrylate, $\mu \mathrm{W}, 130$ ${ }^{\circ} \mathrm{C}, 3$ h, 69\%; (c) i. 1 M LiOH, THF (1:1), RT, 14 h; ii. EDC.HCl, HOBt, DIPEA, DMF, N2, RT, 14 h, 44\%; (d) 10\% Pd/C, H2, RT, 10 bar, 2 h, 86\%; (e) 4 M HCl, RT, 30 min, 39\% for 9, 29\% (over two step from 8) for 11.

Saponification of methyl ester 7 with lithium hydroxide and subsequent amide coupling with tertbutyl (6-aminohexyl)carbamate using 1-ethyl-3-(3-dimethylaminopropyl)carbodiimide hydrochloride (EDC. $\mathrm{HCl})$ and $\mathrm{N}$-hydroxybenzotriazole (HOBt) afforded Boc-protected congener $\mathbf{8}$ in a respectable yield (44\%) with > 95\% purity according to HPLC. An "H-cube" hydrogenation system was then employed to reduce the olefin in the next step (small scales of $500 \mathrm{mg}$ or less). This occurred cleanly within two hours to produce $\mathbf{1 0}$ in high yield (86\%). Acidolytic Boc group removal was performed on both the unreduced (8) and reduced (10) versions of the protected congeners to give compounds 9 and 11 respectively, as their bis- $\mathrm{HCl}$ salts following lyophilization. 
Imide congener. The synthetic route for these derivatives commenced with synthesis of a maleimide-bearing linker group though reaction of $N$-(ethoxycarbonyl)maleimide ${ }^{48}$ with mono-Bocprotected diaminohexane (Scheme 2). After one hour, 12 was obtained as a pure white solid in high yield (89\%). This high yield was only achieved if fresh (no more than a week old) $N$ (ethoxycarbonyl)maleimide was used and if the amine was stirred in saturated $\mathrm{NaHCO}_{3}$ at $0{ }^{\circ} \mathrm{C}$ before adding in the maleimide.

Scheme 2. Synthesis of the imide congener. ${ }^{a}$

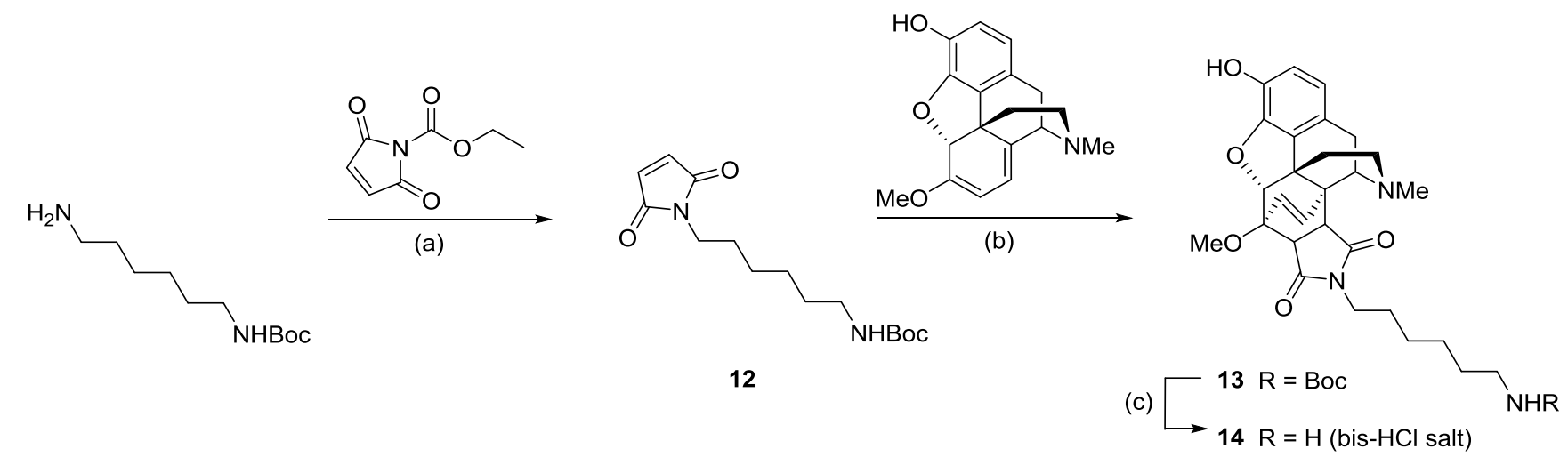

${ }^{a}$ Reagents and conditions: (a) i. 3:5 THF/sat. $\mathrm{NaHCO}_{3}(\mathrm{aq}), 0{ }^{\circ} \mathrm{C}, 15 \mathrm{~min}$; ii. $3: 17$ (v/v) THF/sat. $\mathrm{NaHCO}_{3 \text { (aq) }}$, RT, 45 min, 89\%; (b) EtOH, reflux, 5 h, 52\%; (c) $4 \mathrm{M} \mathrm{HCl,} \mathrm{RT,} 30$ min, 86\%.

Compound 13 was synthesized via a Diels-Alder reaction between 12 and oripavine (Scheme 2). This reaction required less forcing conditions compared to methyl acrylate as the maleimide group is a stronger dienophile. Additionally, as the maleimide is connected through both the 7 and 8 positions, no minor regioisomer byproducts were produced and hence purification was performed via silica chromatography.

Unfortunately, reducing the alkene moiety of these compounds proved problematic. Reaction conditions trialed in the $\mathrm{H}$-cube included pressures as high as $20 \mathrm{bar}$ (280 psi), yet no reduction took place, even after two hours. One possible explanation for this difficulty is that the bulkiness of the 
maleimide group hinders the olefin's approach to the palladium catalyst. Only the unreduced version of this congener was therefore tested, and it was assumed that enough information about the effect of the olefin on potency and affinity could be garnered from the amide congeners. Finally, acidolytic removal of the Boc protecting group of $\mathbf{1 3}$, followed by column chromatography to remove minor impurities, afforded congener $\mathbf{1 4}$ as its bis- $\mathrm{HCl}$ salt.

The different congeners were compared pharmacologically to assess which modifications were tolerated by the MOR and which, if any, retained the partial MOR selectivity of the parent molecule (vide infra). In all cases, the corresponding tert-butyloxycarbonyl (BOC) protected congeners were also evaluated in order to help assess if there was potential receptor tolerance for further chemical elaboration at the end of the linker unit.

Fluorescent ligands synthesis. The four fluorophores chosen for incorporation into our probes were BODIPY ${ }^{\mathrm{TM}}$ 630/650, naphthalimide, sulfo-Cy5 and tetrazine. The necessary precursors were commercially available (BODIPY ${ }^{\mathrm{TM}} 630 / 650 \mathrm{SE}$ ) or readily accessed by literature procedures (sulfoCy5 with a hexanoic acid pendant ${ }^{49}$ and 3-(4-amino-1,8-naphthalimido)propanoic acid ${ }^{50}$ ) for all but the tetrazine probe. Preparation of the later required the synthesis of a novel conjugatable tetrazine derivative (19) from 3,6-dichlorotetrazine (15) $)^{51}$ according to Scheme 3. Compound 18 features a butanoic acid linker at one end and a methoxy "cap" at the other. Such alkoxy groups render tetrazines fluorescent. ${ }^{51-54}$ Additionally, these groups ensure that no other group reacts with the tetrazine via nucleophilic substitution, in particular thiols and amines, which cause loss of tetrazine fluorescence. ${ }^{51}$

Compound 15 was first reacted with excess methanol to replace one of the chloro groups with a methoxy substituent. ${ }^{54}$ Following this, the remaining chloro group was substituted with 1,4-butanediol in low yield (19\%) by adapting the method of Gong et al. ${ }^{53}$ and employing $\mathrm{NaH}$ to deprotonate the alcohol reactant (substitution with 4-hydroxybutanoic acid was also trialed in an attempt to directly access 18, however this led to degradation of the tetrazine core). The low yield of $\mathbf{1 7}$ is thought to be 
due to partial degradation of the tetrazine by the reactive alkoxide, combined with the formation of byproducts resulting from 1,4-butanediol displacing both the methoxy and chloro groups of $\mathbf{1 6}$ or forming crosslinked species (an extra equivalent of the diol was added in an attempt to minimize double-deprotonation of the diol). The penultimate step involved oxidation of the terminal alcohol under mild conditions, employing a catalytic amount of chromium trioxide $(1.2 \mathrm{~mol} \%)$ and periodic acid as per the method of Zhao et al. ${ }^{55}$ Finally, the carboxylic acid group of $\mathbf{1 8}$ was converted to the $N$ hydroxysuccinimide (NHS) ester using dicyclohexylcarbodiimide (DCC) as the coupling reagent. ${ }^{1} \mathrm{H}$ NMR analysis showed that the isolated sample of $\mathbf{1 9}$ contained dicyclohexylurea (DCU, $25 \%$ by mass according to ${ }^{1} \mathrm{H}$ NMR), however it was considered adequate for the subsequent coupling step.

Scheme 3. Synthesis of the conjugatable tetrazine fluorophore. ${ }^{a}$

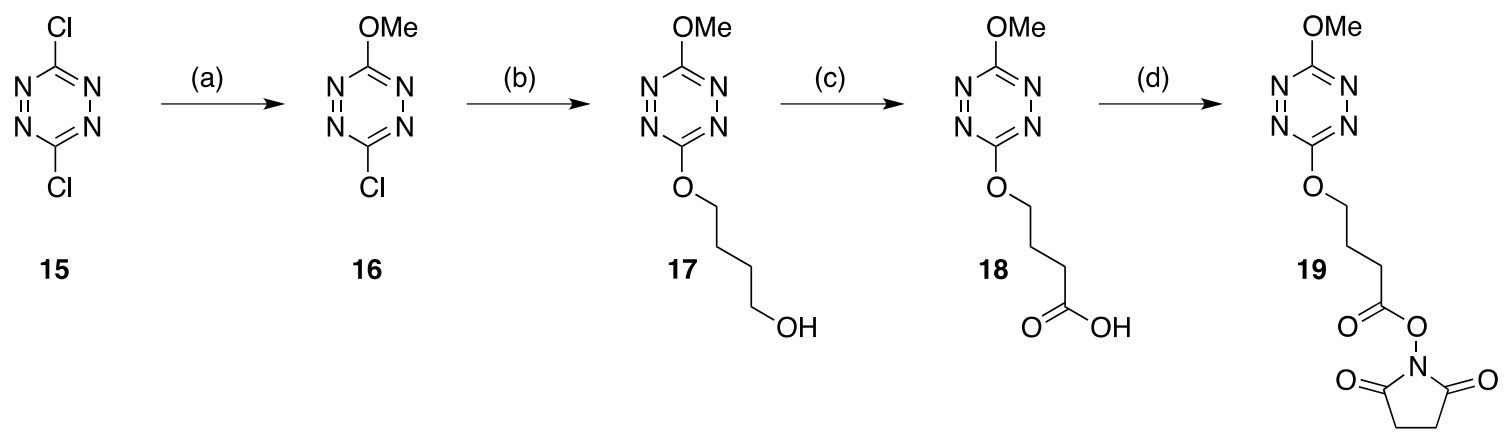

${ }^{a}$ Reagents and conditions: (a) MeOH, RT, 1 h, 82\%; (b) i. NaH, 1,4-butanediol, dry THF, N2, RT, 30 min; ii. $\mathrm{N}_{2}$, dry THF, $-78{ }^{\circ} \mathrm{C}, 1 \mathrm{~h}$; iii. RT, 1 h, 19\%; (c) i. $\mathrm{CrO}_{3}, \mathrm{H}_{5} \mathrm{IO}_{6}, \mathrm{ACN}, 0{ }^{\circ} \mathrm{C}, 30 \mathrm{~min}$; ii. RT, 30 min, 100\%; (d) i. DCC, NHS, DCM, $0{ }^{\circ} \mathrm{C}, 1$ h; ii. RT, 1 h, $97 \%$ recovery $(75 \% 19,25 \%$ DCU by mass $)$.

The final step was to conjugate the fluorophores as per Scheme 4. The amide congener $\mathbf{1 1}$ was selected over the imide congener due to its higher binding affinity (vide infra) (note that the bis-TFA salt form of 11 (11b), rather than the bis- $\mathrm{HCl}$ salt (11a), was used for three of the probes). While BODIPY ${ }^{\mathrm{TM}}$ 630/650 and the tetrazine derivative were reacted as $N$-hydroxysuccinimide esters, 2-(6- 
chloro-1H-benzotriazole-1-yl)-1,1,3,3-tetramethylaminium hexafluorophosphate (HCTU) was used to couple the unactivated naphthalimide and sulfo-Cy5 derivatives to the congener. The naphthalimide probe 1 was isolated in reasonable yield (48\%) via this method, however a guanidiunium byproduct was detected in significant amounts for the sulfo-Cy5 probe $\mathbf{3}$, formed as a result of the amine reacting directly with the coupling reagent. ${ }^{56}$ The use of benzotriazol-1-yl-oxytripyrrolidinophosphonium hexafluorophosphate (PyBOP) as a coupling agent eliminated this problem, although $\mathbf{3}$ could still only be isolated in low yield (18\%).

Conjugation of the BODIPY ${ }^{\mathrm{TM}} 630 / 650$ and tetrazine fluorophores was performed using the reaction conditions set out by Middleton et al. ${ }^{57}$ Purification of 2 required only preparative HPLC (32\% yield), however for 4 , an extra extraction step (1:3 IPA: $\mathrm{CHCl}_{3}$ ) was required to remove the DCU carried over from the previous step (18\% yield).

Scheme 4. Synthesis of fluorescent OR ligands. ${ }^{a}$
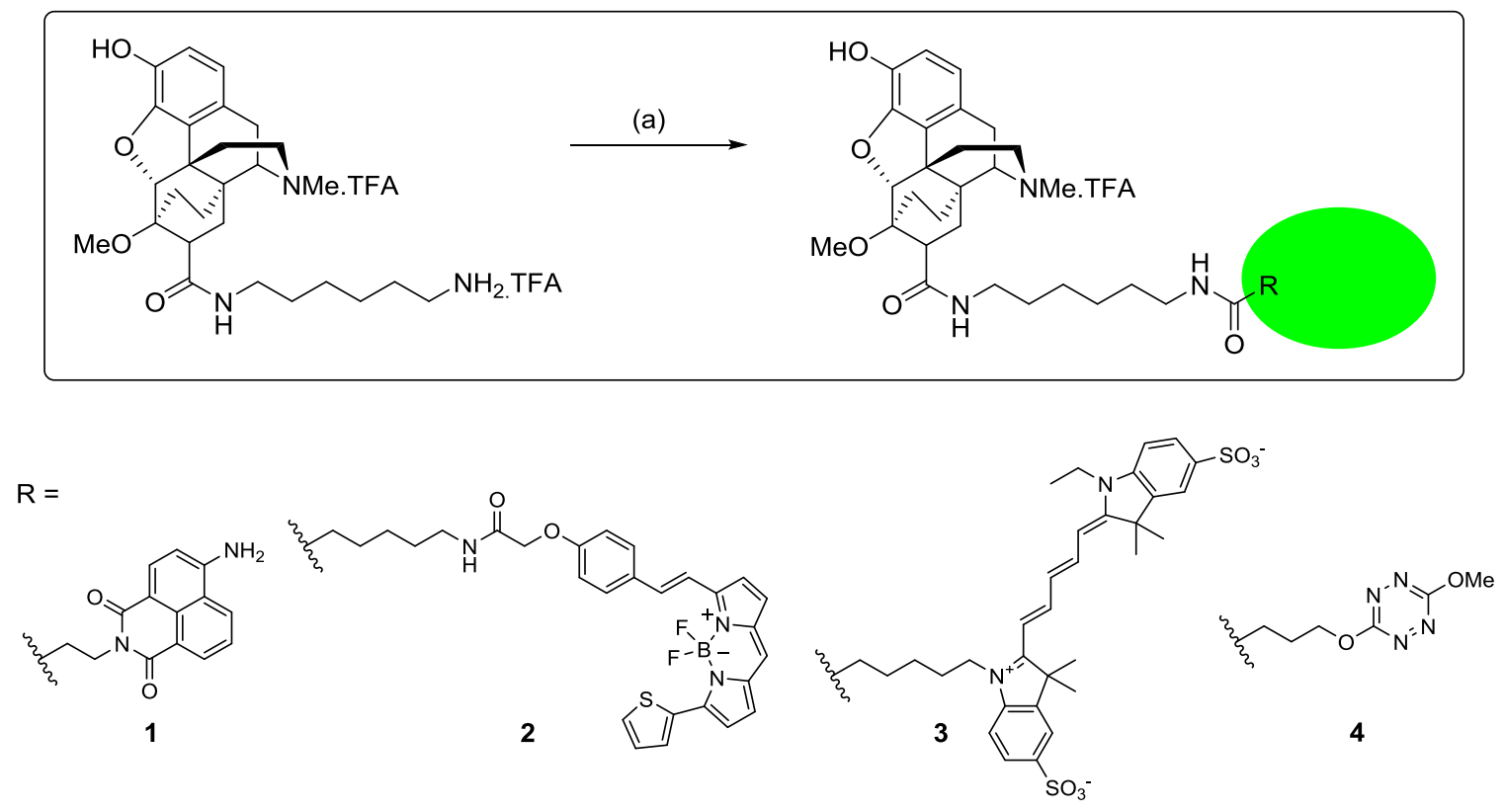
${ }^{a}$ Reagents and conditions: (1) HCTU, DIPEA, N2, dry DMF, 2 h, RT, 48\%; (2) DIPEA, N2, dry DMF, 4 h, RT, 32\%; (3) PyBOP, DIPEA, N2, dry DMF, 1 h, RT, 18\%; (4) DIPEA, N2, dry DMF, 1 h, RT, $18 \%$.

Pharmacology. Initially, the OR binding affinities of the six congeners were measured via a competitive radioligand binding assay using $\left[{ }^{3} \mathrm{H}\right]$ diprenorphine in membrane preparations of $\mathrm{CHO}-$ FlpIn cells stably expressing the human MOR. The results (Table 1) revealed some clear trends. Firstly, the amide linker is generally better tolerated than the imide linker; three of the four compounds (8, 10 and 11) with amide linkers have a higher binding affinity than the imide congeners. The amide equivalent (8) of the protected, unreduced imide congener (13) displayed approximately 35-fold higher affinity for the ORs. One possible explanation for this is that the amide group is more flexible than the imide group and is thus able to rotate itself into a position where it can make more favorable hydrogenbonding interactions with surrounding residues, or minimize unfavorable steric interactions. The reduction of the olefin is associated with a 2-3-fold increase in OR affinity (10 vs. 8 and 11 vs. 9), which may again be due to increased flexibility. Finally, the Boc-protected congeners, 8,10 and 13, exhibited approximately 26-, 49- and 8-fold higher OR affinity compared to the respective deprotected analogs, 9, 11 and 14. This indicates not only that the linker is well tolerated, but that it is sufficiently long that reasonably bulky groups can be attached to its terminus without disrupting binding. 
$\overline{\text { Table 1. OR affinities }\left(\mathrm{p} K_{\mathrm{i}}\right) \text { of congeners, measured using a radioligand binding assay in membrane }}$ preparations of CHO FlpIn cells stably expressing human MOR.

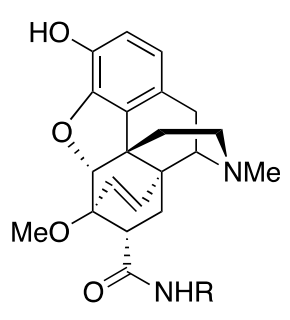

8,9

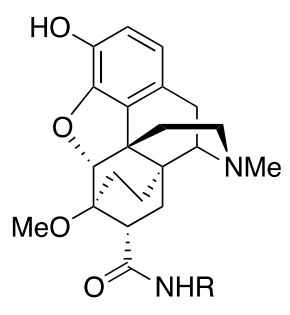

10,11

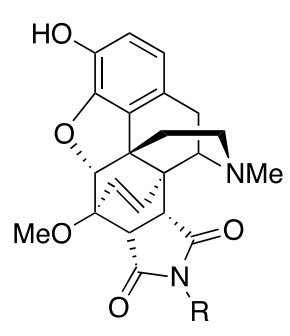

13,14

\begin{tabular}{cccc} 
Compound & $\mathbf{R}$ & Single/Double Bond & $\mathbf{p} \boldsymbol{K}_{\mathbf{i}}$ \\
DAMGO & -- & -- & $5.66 \pm 0.08$ \\
Buprenorphine & -- & -- & $8.8^{\dagger}$ \\
$\mathbf{8}$ & $-\left(\mathrm{CH}_{2}\right)_{6} \mathrm{NHBoc}$ & Double & $8.13 \pm 0.08^{\S}$ \\
$\mathbf{9}$ & $-\left(\mathrm{CH}_{2}\right)_{6} \mathrm{NH}_{2} .2 \mathrm{HCl}$ & Double & $6.71 \pm 0.08$ \\
$\mathbf{1 0}$ & $-\left(\mathrm{CH}_{2}\right)_{6} \mathrm{NHBoc}$ & Single & $8.66 \pm 0.08$ \\
$\mathbf{1 1}$ & $-\left(\mathrm{CH}_{2}\right)_{6} \mathrm{NH}_{2} .2 \mathrm{HCl}$ & Single & $6.97 \pm 0.08$ \\
$\mathbf{1 3}$ & $-\left(\mathrm{CH}_{2}\right)_{6} \mathrm{NHBoc}$ & Double & $6.58 \pm 0.07$ \\
$\mathbf{1 4}$ & $-\left(\mathrm{CH}_{2}\right)_{6} \mathrm{NH}_{2} .2 \mathrm{HCl}$ & Double & $5.69 \pm 0.07$ \\
${ }^{\dagger}$ from IUPHAR database. & \\
\$8 Errors represent \pm SEM of 3 independent experiments & \\
\hline
\end{tabular}

The efficacy of congeners 8-14 to stimulate ERK phosphorylation via the MOR was also tested in CHO FlpIn cells stably expressing human MOR. Time-course experiments involving incubation of the congeners $(10 \mu \mathrm{M})$ with MOR-overexpressing cells for a 30-min period showed no ERK phosphorylation in the presence of any of the congeners (data not shown), indicating that all congeners have no detectable agonist activity at this signaling pathway at this time point. 
Incubation of increasing concentrations of each of the fluorescent probes with an $\mathrm{EC}_{50}$ concentration of a MOR, DOR or KOR agonist ([D-Ala ${ }^{2}, \mathrm{~N}-\mathrm{MePhe}^{4}$, Gly-ol]-enkephalin (DAMGO), SNC80 and ICI199441, respectively) in CHO FlpIn cells stably expressing human MOR, DOR or KOR, resulted in an inhibition of agonist-induced ERK phosphorylation in all cases (Figure S21) (in the case of the DOR and KOR, time course experiments akin to those performed with the congeners and MOR-overexpressing cells were also conducted, indicating that all congeners have no detectable agonist activity at this signaling pathway after $30 \mathrm{~min}$ (data not shown)). Assuming competitive binding, the affinities $\left(\mathrm{pA}_{2}\right)$ of the fluorescent probes for the three receptor subtypes (Table 2) were determined using the Gaddum-Schild equation as per Lane et al. ${ }^{59}$ Each of the probes showed high affinity for the MOR, together with a strong preference for this OR subtype over KOR and DOR (selectivity ratios of 9-45 and > 200, respectively). The selectivity ratios for 2 and 4 indicate that they are amongst the most MOR-selective fluorescent opiate antagonists reported to date. ${ }^{25-27}$

Table 2. $\mathrm{pA}_{2}$ values of the fluorescent probes at the three ORs $(\mathrm{n}=3)$. Agonists used were DAMGO (MOR), SNC80 (DOR) and ICI199441 (KOR).

\begin{tabular}{|c|c|c|c|c|}
\hline Compound & pAt2 (MOR) & $\mathbf{p A} 2$ (DOR) & pA2 (KOR) & $\begin{array}{c}\text { MOR/KOR } \\
\text { selectivity }\end{array}$ \\
\hline Agonist (pEC50) & $7.67 \pm 0.01^{\S}$ & $8.18 \pm 0.07$ & $10.32 \pm 0.04$ & - \\
\hline 1 & $7.87 \pm 0.08$ & $<5^{\#}$ & $6.91 \pm 0.18$ & 9 \\
\hline 2 & $8.37 \pm 0.07$ & $<5$ & $6.72 \pm 0.25$ & 45 \\
\hline 3 & $7.31 \pm 0.22$ & $<5$ & $6.30 \pm 0.04$ & 10 \\
\hline 4 & $8.01 \pm 0.27$ & $<5$ & $6.37 \pm 0.04$ & 44 \\
\hline \multicolumn{5}{|c|}{$\begin{array}{l}{ }^{\S} \text { Errors represent } \pm \text { SEM of three independent experiments performed in triplicate. }{ }^{\#}<5 \text { indicates that } \\
\text { no fitting could be performed within the concentrations tested, indicating very low affinity. }\end{array}$} \\
\hline
\end{tabular}


Imaging studies. The absorption and emission profiles of the synthesized probes (Figure S23) were recorded using a FlexStation 3 plate reader in both hydrophilic (HEPES buffered saline solution, HBSS) and hydrophobic (dimethylsulfoxide, DMSO) environments at a concentration of $10 \mu \mathrm{M}$. These solvents were used to represent the polar aqueous and comparatively non-polar ligand binding site environment within an OR, respectively. Such measurements were necessary to ensure that appropriate excitation wavelength and dichroic emission filters were used in the subsequent imaging experiments.

In general, all of the observed excitation and emission maxima (Table S1) closely matched those reported in the literature for the corresponding "free" fluorophore. ${ }^{50,60,61}$ All probes experienced a significant decrease in emission intensity and, in most cases, a hypsochromic shift in maxima upon moving from DMSO to HBSS, which is particularly useful from the perspective of developing fluorescent displacement-style binding assays. Unfortunately, no signal could be detected for the tetrazine probe, $\mathbf{4}$, even at $100 \mu \mathrm{M}$, despite the fact that yellow fluorescence could be observed under long-wavelength UV irradiation (TLC lamp).

It was encouraging that the BODIPY ${ }^{\mathrm{TM}} 630 / 650$ derivative (2) exhibited the highest MOR affinity (vide supra) as it has particularly favorable photophysical properties for imaging and assay applications. Most BODIPY fluorophores have high quantum yields, often approaching unity, and a high molar extinction coefficient $\left(101,000 \mathrm{~cm}^{-1} \mathrm{M}^{-1}\right){ }^{62}$ Probe 2 displayed bright fluorescence in a relatively non-polar environment (DMSO), but almost full quenching of fluorescence in an aqueous environment (Figure S23), which would obviate the need for a washing step in a fluorescent displacement-style binding assay.

Single-time point confocal images of human embryonic kidney cells (HEK) stably expressing the human MOR-GFP fusion protein were captured after incubation with each of the probes (Figure 3). 
The MOR was expressed with green fluorescent protein at its C-terminus so that the binding specificity of each probe could be assessed from the degree of co-localization of probe and GFP fluorescence.

The strong binding affinity and favorable photophysical properties of BODIPY ${ }^{\mathrm{TM}}$ 630/650 allowed probe 2 to be clearly imaged at relatively low concentration $(5 \mathrm{nM})$. There was a high degree of colocalization of the probe with MOR-GFP and significant displacement of binding by the nonfluorescent antagonist, naloxone, providing strong evidence that binding is specifically to the MOR. However, the fact that not all the fluorescent signal was lost upon incubation with a large excess of the unlabeled MOR-specific ligand indicates some degree of non-specific interaction of 2 with the cellular membrane (Figure 3).

The concentration required to image binding of probe $3(50 \mathrm{nM})$ was higher than that required for 2, consistent with its almost 10-fold lower affinity for the MOR. Unlike 2 , this probe could be almost completely displaced using excess naloxone (Figure 3), again indicating that it binds specifically to the MOR, but also that the use of a more hydrophilic sulfo-Cy5 fluorophore reduces non-specific interaction with the cellular membrane.

Displacement of $\mathbf{3}$ with naloxone was also accompanied by a large decrease in fluorescence intensity, consistent with the reduced fluorescence of this probe in an aqueous environment. It should be noted that no wash steps were performed in these imaging experiments, so the observed reductions in fluorescence were not simply due to a concentration gradient-driven re-equilibration process.

In the case of $\mathbf{1}$ and $\mathbf{4}$, no fluorescence was observed after incubating cells with the probes; hence their quantum yields appear to be inadequate for imaging purposes under the conditions employed here. 
MOR-GFP
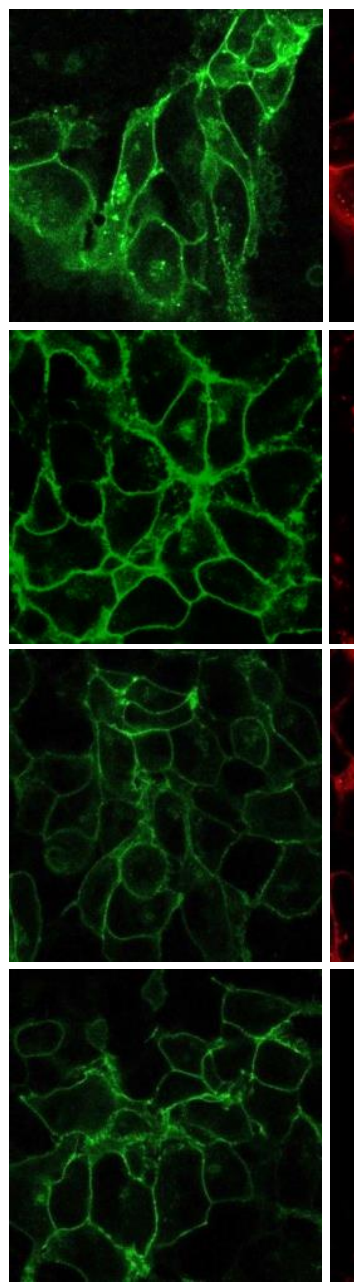

Ligand
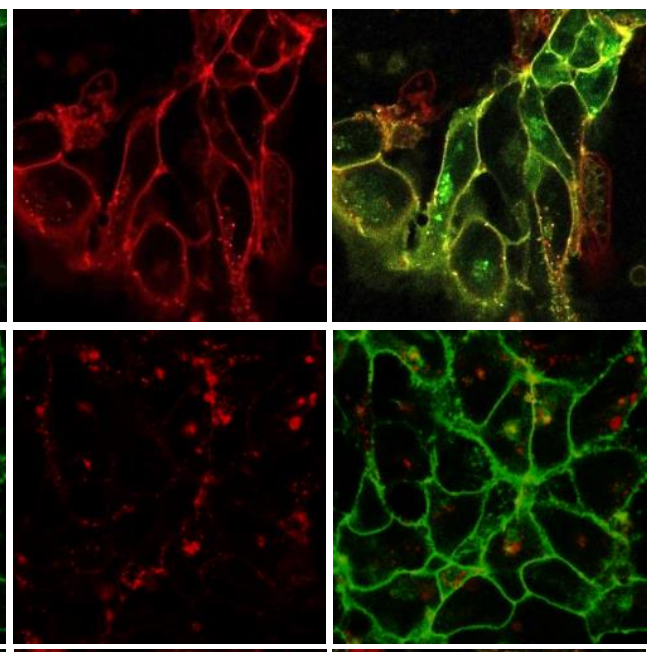

$2(5 \mathrm{nM})$

$2(5 \mathrm{nM})$

$+1 \mu \mathrm{M}$ Naloxone

$3(50 \mathrm{nM})$
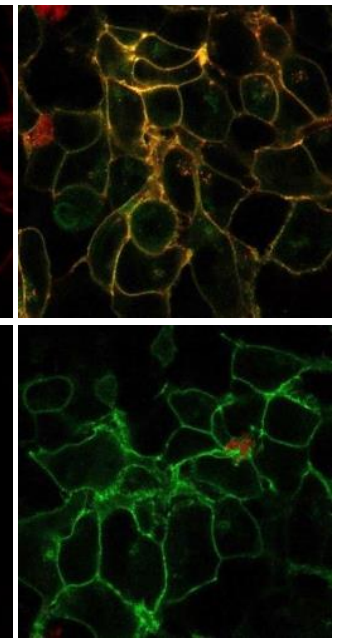
(5

1 $\mu$ M Naloxone
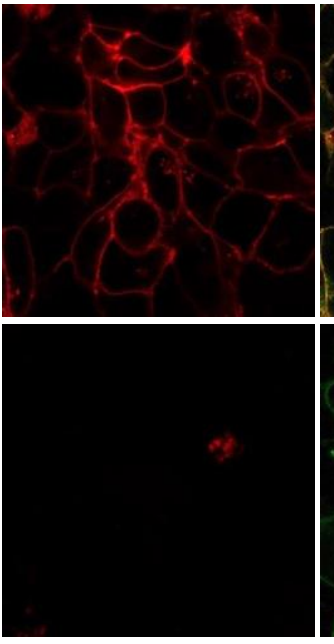

$3(50 \mathrm{nM})$

$+1 \mu \mathrm{M}$ Naloxone

Figure 3. Live cell confocal imaging of 2 and 3 in cells expressing MOR-GFP. Confocal images of HEK-MOR-GFP cells incubated with probes 2 or $3\left(30 \mathrm{~min}, 37^{\circ} \mathrm{C}\right)$ at the concentrations shown, with and without prior incubation with naloxone $\left(1 \mu \mathrm{M}, 30 \mathrm{~min}, 37^{\circ} \mathrm{C}\right)$. All images are of a $102 \mu \mathrm{m} \times 102$ $\mu \mathrm{m}$ area and are representative images of those obtained in three separate experiments.

Fluorescent binding assays. The imaging studies suggested that probes $\mathbf{2}$ and $\mathbf{3}$ may be suitable for use in a fluorescence-based competition binding assay as per Stoddart et al. ${ }^{63}$ As a prelude to this, experiments were performed to establish an appropriate pre-incubation time (Figure 4). 
The results for the sulfo-Cy5-bearing probe $\mathbf{3}$ (Figure 4, top panels) showed that equilibrium was rapidly reached (within $5 \mathrm{~min}$ ), whilst for the BODIPY-bearing probe 2 (Figure 4, bottom panels), the system was still equilibrating after 30 minutes. Experiments performed in the presence of an excess of naloxone again confirmed that there was minimal non-specific interaction in the case of $\mathbf{3}$, and a single wash step removed essentially all of the bound probe, reflective of fast dissociation kinetics. In contrast, significant amounts of $\mathbf{2}$ bound to the cells in the presence of naloxone, and washing produced very little change in fluorescence, indicating a high degree of non-specific interaction and/or slower dissociation kinetics. Given these results, $\mathbf{3}$ was considered the most appropriate probe for use in a fluorescent binding assay. 
Not washed

Washed

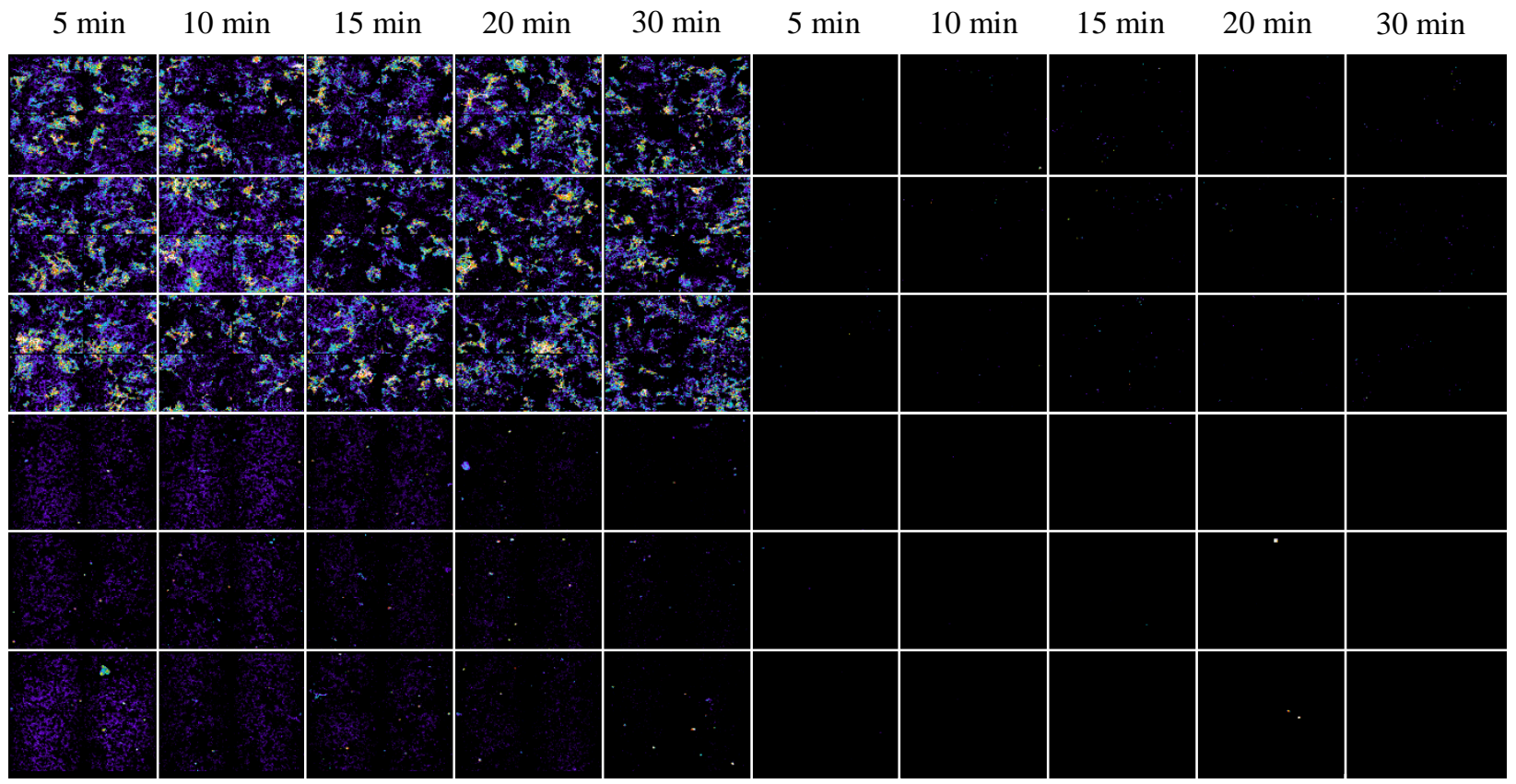

$100 \mathrm{nM} 3$

$100 \mathrm{nM} 3$

$+1 \mu \mathrm{M}$

Naloxone

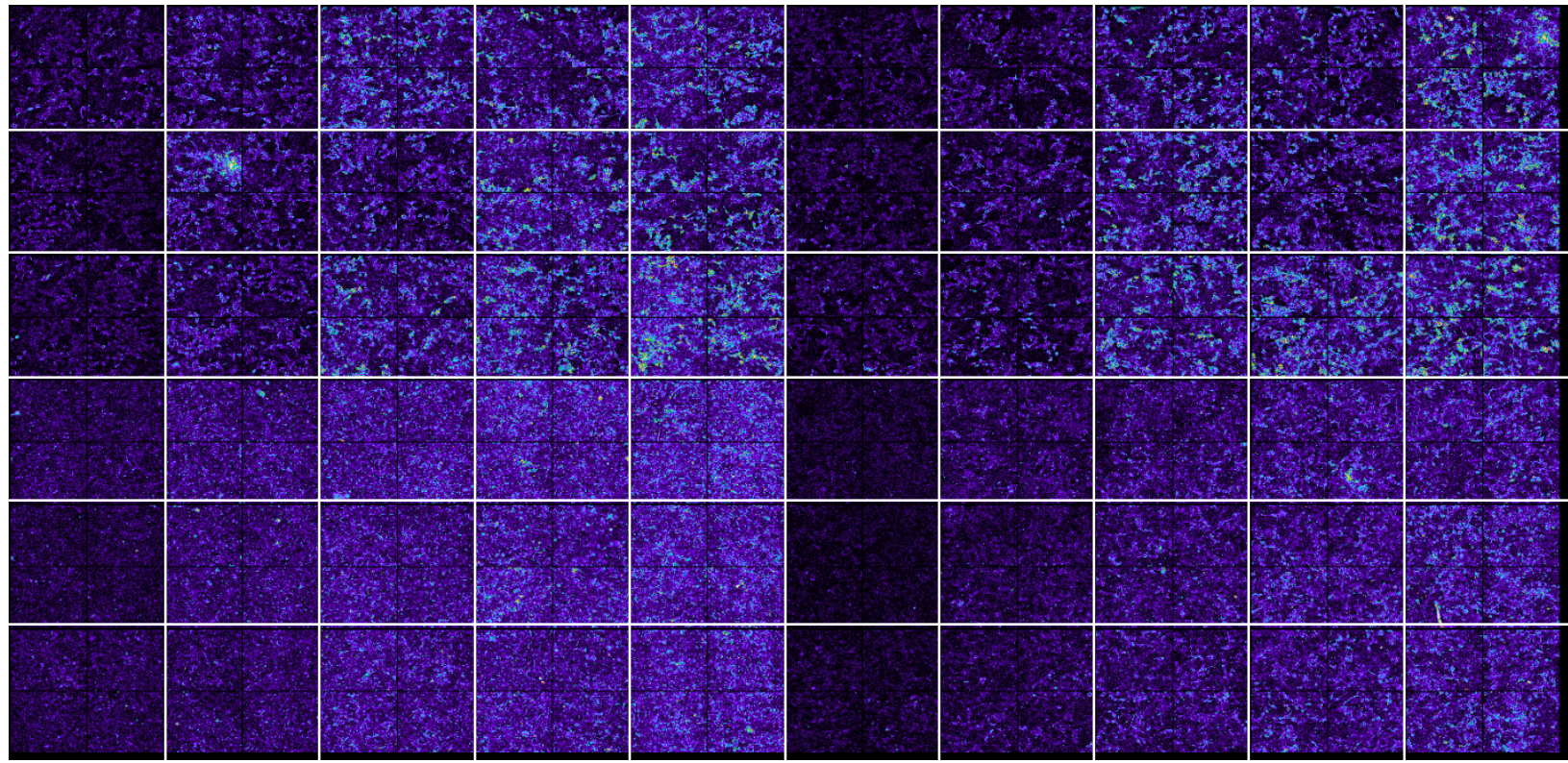

$10 \mathrm{nM} 2$

$10 \mathrm{nM} 2$

$+1 \mu \mathrm{M}$

Naloxone

Figure 4. Determining the suitability of 2 and 3 for a live cell fluorescence-based competition

binding assay. Confocal images obtained on the IX Ultra of HEK-MOR cells incubated with 2 (10 $\mathrm{nM})$ and $\mathbf{3}(100 \mathrm{nM})$ for $5-30 \mathrm{~min}$ at $37^{\circ} \mathrm{C}$. Cells in the bottom three rows of the plate were coincubated with naloxone $(1 \mu \mathrm{M})$ for their respective time periods, and those in the five right-hand side columns 
were washed once after incubation. The image is a montage of four images taken per well and is representative of images taken in three separate experiments.

To confirm that $\mathbf{3}$ was suitable for use in determining the affinity of unlabeled ligands, MOR receptor-expressing cells were co-incubated with $\mathbf{3}(50 \mathrm{nM})$ and increasing concentrations of either the MOR agonists, DAMGO and dermorphin, or the MOR antagonists, diprenorphine, naloxone, naltrexone and naloxonazine, with xanthine amine congener (XAC), an adenosine receptor antagonist included as a negative control. The affinity of each test compound ( $\mathrm{p} K_{\mathrm{i}}$, Table 3 ) was determined from the $\mathrm{IC}_{50}$ value obtained from the competition curve constructed by measuring the decrease in fluorescence intensity caused by the compound competing with $\mathbf{3}$ for the MOR (Figure 5).

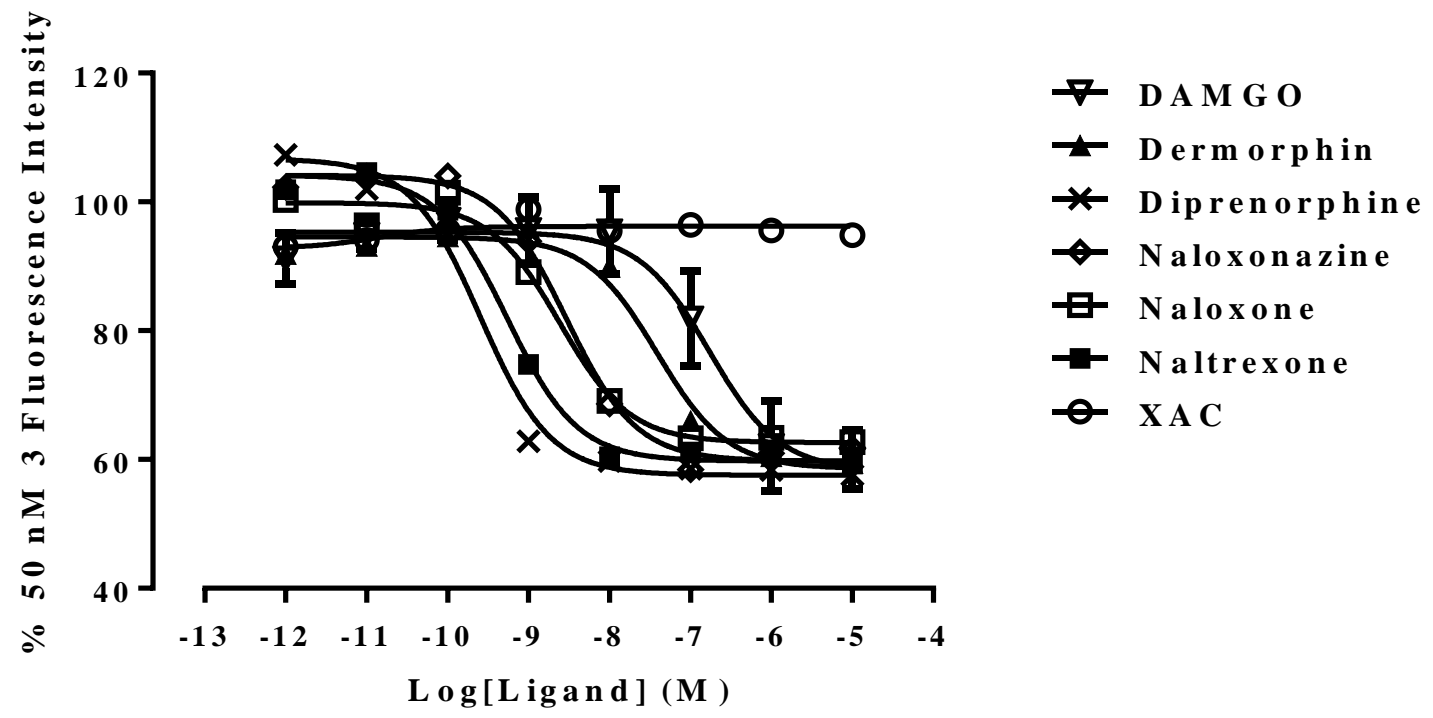

Figure 5. Competition binding curves. Competition curves for displacement of 3 (50 nM) by MORbinding test compounds and XAC, constructed by measuring the decrease in fluorescence intensity with increasing concentrations of test compound. Each data point represents mean \pm SEM of three experiments each performed in duplicate. 
For the antagonists, excellent agreement was found between the $\mathrm{p} K_{\mathrm{i}}$ values obtained from the automated confocal imaging and literature values derived from radioligand binding assays (Table 3 ). In contrast, the $\mathrm{p} K_{\mathrm{i}}$ values obtained for the agonists were significantly lower than the literature values. ${ }^{64-67}$ However, it is of note that the literature values were obtained from radioligand binding assays using a titrated agonist $\left(\left[{ }^{3} \mathrm{H}\right] \mathrm{DAMGO}\right)$. As such, the affinities reported in literature represent the high-affinity $\mathrm{G}$ protein-coupled state of the receptor. As our fluorescent ligand competition binding assays were performed in whole cells, where the intracellular concentration of GDP is significantly higher than GTP, the receptor will exist predominantly in the low-affinity G protein uncoupled state state, which is reflected in the lower agonist affinities obtained. As expected, no decrease in fluorescence intensity was observed in the presence of XAC, meaning that there is no decrease in binding of the probe over time and its binding is specific to the MOR.

Table 3. MOR affinity $\left(\mathrm{p} K_{\mathrm{i}}\right)$ of test compounds, as determined by Cheng-Prusoff analysis of data presented in Figure $5(\mathrm{n}=3)$. Literature values derived from radioligand binding assays are included for comparison. ${ }^{64-67}$

Compound DAMGO

Dermorphin

Diprenorphine

Naloxonazine

Naloxone

Naltrexone $\mathrm{p} K_{\mathrm{i}}$ from fluorescent binding assay

$$
7.06 \pm 0.13^{\S}
$$$$
7.71 \pm 0.08
$$$$
9.91 \pm 0.08
$$$$
8.84 \pm 0.05
$$$$
8.94 \pm 0.11
$$$$
9.56 \pm 0.04
$$

\section{Literature $\mathrm{p} K_{\mathrm{i}}$}

$$
8.9
$$

8.8

9.7

8.5

8.9

9.7

$\S^{\S}$ Errors represent \pm SEM of three independent experiments performed in duplicate. 


\section{- CONCLUSION}

In conclusion, we have successfully synthesized four new non-peptidic fluorescent OR ligands based on the buprenorphine scaffold. All four compounds acted as antagonists at the MOR, DOR and KOR, exhibiting highest affinity for the MOR. Although we have not yet explored the NOR-binding properties of the compounds, the fact that buprenorphine has affinity for this fourth OR subtype suggests that this would be a worthwhile subject for future studies. The ligand linked to the sulfo-Cy5 fluorophore (3) was found to display the best properties for use in imaging and fluorescent binding assays, exhibiting rapid and reversible MOR binding, characterized by increased fluorescence in the bound state. It was successfully used to image the MOR in HEK cells overexpressing this receptor, as well as to measure the MOR affinities of a series of ligands via a fluorescent competitive binding assay. We envisage that this compound will prove useful as a research tool for further investigating the pharmacology of the MOR in in vitro studies, as well as in developing new OR agonists/antagonists with improved efficacy and side-effect profiles. 


\section{- EXPERIMENTAL SECTION}

Chemistry. All chemicals were purchased from Sigma-Aldrich Pty, Invitrogen, Matrix Scientific, Tocris Bioscience or Merck Group Ltd and used without purification, unless otherwise indicated. tertButyl-(6-aminohexyl)carbamate, triaminoguanidine hydrochloride, 3,6-bis(3,5-dimethyl1H-pyrazol-1yl)-1,2-dihydro-s-tetrazine, $\quad$ 3,6-bis(3,5-dimethyl1H-pyrazol-1-yl)-s-tetrazine, $\quad$ 3,6-dihydrazinyl-stetrazine, $\mathbf{1 5}$ and $\mathbf{1 6}$ were synthesized as per previous literature. ${ }^{51,54,68}$ All solvents were reagent grade (chloroform, dichloromethane, ethyl acetate, methanol, acetonitrile). Microwave reactions were conducted in a Biotage Initiator ${ }^{\mathrm{TM}}$, in $0.5-2.0 \mathrm{~mL}$ vials unless otherwise indicated, according to the manufacturer's instructions. Where indicated, reduction reactions were performed using a Thalesnano Hydrogenation Reactor $\left(\mathrm{H}_{-} \mathrm{Cube}^{\mathrm{TM}}\right.$ ) continuous flow apparatus system using a $10 \% \mathrm{PD} / \mathrm{C}$ Catcart $^{\mathrm{TM}}$ cartridge with parameters as indicated. Thin layer chromatography (TLC) was performed on Merck Silica Gel 60 F254 plates. TLC plates were visualized using a UV lamp at $254 \mathrm{~nm}$ or through the use of $\mathrm{KMnO}_{4}$ staining agent. ${ }^{1} \mathrm{H},{ }^{13} \mathrm{C}$ and ${ }^{19} \mathrm{~F}$ nuclear magnetic resonance (NMR) spectra were recorded at 400.13 MHz, 100.61 and $376 \mathrm{MHz}$, respectively, using an Avance III Nanobay $400 \mathrm{MHz}$ Bruker spectrometer coupled to the BACS 60 automatic sample changer. Data acquisition and processing was managed using Topspin software package version 3. Chemical shifts $(\delta)$ were measured in parts per million (ppm) referenced to an internal standard of residual solvent; $3.31 \mathrm{ppm}$ and $49.00 \mathrm{ppm}$ for deuterated methanol, $7.26 \mathrm{ppm}$ and $77.16 \mathrm{ppm}$ for deuterated chloroform, $2.50 \mathrm{ppm}$ and $39.52 \mathrm{ppm}$ for deuterated dimethylsulfoxide ( $d_{6}$-DMSO), for proton and carbon spectra, respectively. Spectroscopic data are given using the following abbreviations: s, singlet; d, doublet; t, triplet; q, quartet; $\mathrm{m}$, multiplet; br, broad; $J$, coupling constant; app, apparent pentet. Analytical high-performance liquid chromatography (HPLC) was carried out on a Waters 2690 Separation Module coupled with a Waters 996 Photodiode Array Detector with a Phenomenex Luna 5 micron C8 $150 \times 4.6 \mathrm{~mm}$ column using the following elution protocol: $0-10$ min, gradient from $0 \%$ to $80 \%$ buffer $\mathrm{B} / 20 \%$ buffer $\mathrm{A}, 10-11 \mathrm{~min}$, 
$80 \%$ buffer B/20\% buffer A, 11-12 min, gradient from $80 \%$ buffer B/20\% buffer A to $100 \%$ buffer B; 12-22 min, 100\% B (buffer $\mathrm{A}=99.9 \% \mathrm{H}_{2} \mathrm{O}, 0.1 \%$ TFA; buffer $\mathrm{B}=80 \%$ ACN, $19.9 \% \mathrm{H}_{2} \mathrm{O}, 0.1 \%$ TFA). Compound 3 was analyzed using an Agilent 1260 Infinity Analytical HPLC using a Zorbax Eclipse Plus Rapid Resolution 3.5 micron C18 4.6 x 100 mm, column with a 1260 infinity diode array detector, and the following elution protocol: 0-9 min, gradient from 5\% buffer D/ 95\% buffer C to $100 \%$ buffer D; 9-10 min, $100 \%$ buffer D (buffer $\mathrm{C}=99.9 \% \mathrm{H}_{2} \mathrm{O}, 0.1 \%$ TFA; buffer $\mathrm{D}=99.9 \% \mathrm{ACN}$, $0.1 \%$ TFA). The purities of all compounds submitted for biological testing were hence determined to be $\geq 95 \%$. Preparatory HPLC purification was carried out on an Agilent 1260 Prep HPLC with an Alltima 5 micron C8 250 x $22 \mathrm{~mm}$ column and a 1260 Infinity diode array detector VL, and the following elution protocol: 0-9 min, gradient from 5\% buffer D/ 95\% buffer C to 100\% buffer D; 9-10 min, $100 \%$ D (buffer $\mathrm{C}=99.9 \% \mathrm{H}_{2} \mathrm{O}, 0.1 \%$ TFA; buffer D 99.9\% ACN, 0.1\% TFA). High-resolution mass spectrometric (HRMS) analyses were performed on a Waters LCT TOF LC/MS Mass Spectrometer coupled to a 2795 Alliance Separations module. All data were acquired and mass corrected via a dual-spray Leucine Enkephaline reference sample. Mass spectra were created by averaging the scans across each peak and background subtracted of the TIC. Acquisition and analysis were performed using the MassLynx software version 4.1. The mass spectrometer conditions were as follows: electrospray ionization mode, desolvation gas flow of $550 \mathrm{~L} \mathrm{~h}^{-1}$, desolvation temperature of $250{ }^{\circ} \mathrm{C}$, source temperature of $110^{\circ} \mathrm{C}$, capillary voltage of $2400 \mathrm{~V}$, sample cone voltage of $60 \mathrm{~V}$, scan range acquired between $100-1500 \mathrm{~m} / \mathrm{z}$, one sec scan times and internal reference ions for positive ion mode (Leucine Enkephaline) of 556.2771. Reverse-phase chromatography was performed using Davasil C18-modified reverse-phase silica using buffers C and D. Liquid chromatography-mass spectrometry (LC-MS) was performed using an Agilent 6100 Series Single Quad LC/MS coupled to an Agilent 1200 Series HPLC with the following conditions and equipment for MS: 1200 Series G1311A Quaternary pump, 1200 Series G1329A Thermostatted Autosampler, 1200 Series G1314B Variable 
Wavelength Detector. MS conditions: Quadrupole ion source, multimode-ES ion mode, $300{ }^{\circ} \mathrm{C}$ drying gas temperature, $200{ }^{\circ} \mathrm{C}$ vaporizing temperature, capillary voltage of $2000 \mathrm{~V}$ (positive), capillary voltage of $4000 \mathrm{~V}$ (negative), scan range between 100-1000 m/z with an $0.1 \mathrm{sec}$ step size and a $10 \mathrm{~min}$ acquisition time. LC equipment and conditions were as follows: reverse-phase HPLC analysis on a Luna 5 micron C8(2) $50 \times 4.6 \mathrm{~mm}$ column using a column temperature of $30^{\circ} \mathrm{C}$, an injection volume of $5 \mu \mathrm{L}$, and the following elution protocol: 0-4 min, gradient from 5\% buffer $\mathrm{F} / 95 \%$ buffer $\mathrm{E}$ to 100\% buffer F; 4-7 min, 100\% buffer F; 4-7 min, gradient from 100\% buffer F to 5\% F/95 \% buffer E (buffer $\mathrm{E}=99.9 \% \mathrm{H}_{2} \mathrm{O}, 0.1 \%$ formic acid; buffer $\mathrm{F}$ : $99.9 \% \mathrm{ACN}, 0.1 \%$ formic acid). Detection was at $254 \mathrm{~nm}$. Emission and excitation spectra were obtained using a FlexStation 3. All measurements were made on $10 \mu \mathrm{M}$ solutions of compounds in HBSS or DMSO, with the solvent signals subtracted from the relevant spectra. The following parameters were used. Compound 1: Emission spectra: excitation at $400 \mathrm{~nm}$, cutoff at $420 \mathrm{~nm}$, scan emission from 430-750 nm at $2 \mathrm{~nm}$ steps. Excitation spectra: emission at $580 \mathrm{~nm}$, cutoff at $570 \mathrm{~nm}$, scan excitation from 300-550 nm at $2 \mathrm{~nm}$ steps. Compound 2: Emission spectra: excitation at $360 \mathrm{~nm}$, cutoff at $420 \mathrm{~nm}$, scan emission from 430-710 nm at $2 \mathrm{~nm}$ steps. Excitation spectra: emission at $700 \mathrm{~nm}$, cutoff at $695 \mathrm{~nm}$, scan excitation from 300-680 nm at 2 nm steps. Compound 3: Emission spectra: excitation at $590 \mathrm{~nm}$, cutoff at $610 \mathrm{~nm}$, scan emission from 620-800 nm at $2 \mathrm{~nm}$ steps. Excitation spectra: emission at $700 \mathrm{~nm}$, cutoff at $695 \mathrm{~nm}$, scan excitation from 300-680 nm at $2 \mathrm{~nm}$ steps. All measurements were normalized and plotted using GraphPad Prism 6 (GraphPad Software, San Diego, CA).

(3R, 6S, 7R, 7aR,12bS)-6-((6-(3-(6-Amino-1,3-dioxo-1H-benzo[de]isoquinolin-2(3H)yl)propanamido)hexyl)carbamoyl)-9-hydroxy-7-methoxy-3-methyl-1,2,3,4,5,6,7,7a-octahydro-4a,7ethano-4,12-methanobenzofuro[3,2-e]isoquinolin-3-ium 2,2,2-trifluoroacetate (1). Compound 11a (351 mg, $0.649 \mathrm{mmol})$ and DIPEA $(340 \mu \mathrm{l}, 1.95 \mathrm{mmol})$ were dissolved in dry DMF (2 mL). 3-(4- 
Amino-1,8-naphthalimido)propanoic acid (140 mg, $0.492 \mathrm{mmol})$ and HCTU (247 mg, $0.597 \mathrm{mmol})$ were added to this solution, pre-dissolved in dry DMF $(2 \mathrm{~mL})$. The reaction mixture was left to stir under a nitrogen atmosphere for $2 \mathrm{~h}$. Compound $\mathbf{1}$ was obtained as a green-yellow solid after reversephase column chromatography $\left(0-40 \%\right.$ buffer D in C) and lyophilization $(201 \mathrm{mg}, 48 \%) .{ }^{1} \mathrm{H}$ NMR (MeOD) $\delta_{\text {Hн }} 8.49-8.45(\mathrm{~m}, 2 \mathrm{H}), 8.25(\mathrm{~d}, J=8.4 \mathrm{~Hz}, 1 \mathrm{H}), 7.62(\mathrm{dd}, J=8.4,7.4 \mathrm{~Hz}, 1 \mathrm{H}), 6.86(\mathrm{~d}, J=$ $8.4 \mathrm{~Hz}, 1 \mathrm{H}), 6.74(\mathrm{~d}, J=8.1 \mathrm{~Hz}, 1 \mathrm{H}), 6.65(\mathrm{~d}, J=8.1 \mathrm{~Hz}, 1 \mathrm{H}), 4.56(\mathrm{~d}, J=1.9 \mathrm{~Hz}, 1 \mathrm{H}), 4.40(\mathrm{t}, J=7.0$ $\mathrm{Hz}, 2 \mathrm{H}), 3.70(\mathrm{~d}, J=6.9 \mathrm{~Hz}, 1 \mathrm{H}), 3.41(\mathrm{~s}, 3 \mathrm{H}), 3.29-3.28(\mathrm{~m}, 1 \mathrm{H}), 3.17-3.06(\mathrm{~m}, 5 \mathrm{H}), 2.99(\mathrm{~s}, 3 \mathrm{H})$, $2.90(\mathrm{dd}, J=19.9,7.1 \mathrm{~Hz}, 1 \mathrm{H}), 2.73-2.69(\mathrm{~m}, 1 \mathrm{H}), 2.60-2.52(\mathrm{~m}, 3 \mathrm{H}), 2.30(\mathrm{td}, J=13.7,5.2 \mathrm{~Hz}, 1 \mathrm{H})$, $2.07-1.87(\mathrm{~m}, 3 \mathrm{H}), 1.55-1.41(\mathrm{~m}, 7 \mathrm{H}), 1,25-1.23(\mathrm{~m}, 4 \mathrm{H}), 0.84-0.78(\mathrm{~m}, 1 \mathrm{H}) ;{ }^{13} \mathrm{C} \mathrm{NMR}(\mathrm{MeOD}) \delta_{\mathrm{CH}}$ $174.0,173.5,166.0,165.4,154.4,147.5,140.8,135.5,132.5,131.3,131.1,130.2,125.2,124.3,123.1$, 121.2, 121.0, 119.4, 107.7, 109.4, 92.6, 77.1, 64.8, 52.2, 47.7, 45.4, 44.4, 42.7, 40.3, 40.2, 37.8, 37.1, 35.8, 33.1, 30.7, 30.1, 30.0, 29.7, 27.3, 27.2, 25.2, 19.0; ${ }^{19} \mathrm{~F}$ NMR (MeOD) $\delta$-76.8. HRMS (ESI-TOF) $m / z \mathrm{C}_{42} \mathrm{H}_{49} \mathrm{~N}_{5} \mathrm{O}_{7}[\mathrm{MH}]^{+}$calcd, 735.3632; found, 735.3622.

\section{5,5-Difluoro-3-((Z)-4-(2-((6-((6-)((3R,6S,7R,7aR,12bS)-9-hydroxy-7-methoxy-3-methyl-}

1,2,3,4,5,6,7,7a-octahydro-4a,7-ethano-4,12-methanobenzofuro[3,2-e]isoquinolin-3-ium-6carboxamido)hexyl)amino)-6-oxohexyl)amino)-2-oxoethoxy)styryl)-7-(thiophen-2-yl)-5H-

dipyrrolo[1,2-c:2',1'-f][1,3,2]diazaborinin-4-ium-5-uide 2,2,2-trifluoroacetate (2). Compound 11b (13.8 mg, $19.8 \mu \mathrm{mol})$, DIPEA $(10 \mu \mathrm{l}, 57.4 \mu \mathrm{mol})$ and 6-(((4,4-difluoro-5-(2-thienyl)-4-bora-3a,4adiaza-s-indacene-3-yl)styryloxy)acetyl)aminohexanoic acid, succinimidyl ester (6.70 mg, 10.1 $\mu$ mol) was dissolved in dry DMF $(500 \mu \mathrm{l})$. The reaction was left to stir under a nitrogen atmosphere for $4 \mathrm{~h}$ with the exclusion of light. The resulting solution was added to $\mathrm{MeOH}$ and purified by reverse-phase prep HPLC (60-100\% buffer D in C) to give compound 2 as a blue solid after lyophilization (3.60 mg, 32\%). ${ }^{1} \mathrm{H}$ NMR $(\mathrm{MeOD}) \delta_{\mathrm{HH}} 8.12(\mathrm{dd}, J=3.8,1.0 \mathrm{~Hz}, 1 \mathrm{H}), 7.65-7.60(\mathrm{~m}, 3 \mathrm{H}), 7.55(\mathrm{~d}, J=4.0 \mathrm{~Hz}$, 2H), $7.37(\mathrm{~s}, 1 \mathrm{H}), 7.22-7.20(\mathrm{~m}, 2 \mathrm{H}), 7.14(\mathrm{~d}, J=4.4 \mathrm{~Hz}, 2 \mathrm{H}), 7.06(\mathrm{~d}, J=8.9 \mathrm{~Hz}, 2 \mathrm{H}), 6.86(\mathrm{~d}, J=4.3$ 
$\mathrm{Hz}, 1 \mathrm{H}), 6.74(\mathrm{~d}, J=8.1 \mathrm{~Hz}, 1 \mathrm{H}), 6.63(\mathrm{~d}, J=8.1 \mathrm{~Hz}, 1 \mathrm{H}), 4.57(\mathrm{~s}, 2 \mathrm{H}), 4.51(\mathrm{~d}, J=1.9 \mathrm{~Hz}, 1 \mathrm{H}), 3.62$ $(\mathrm{d}, J=6.9 \mathrm{~Hz}, 1 \mathrm{H}), 3.38(\mathrm{~s}, 3 \mathrm{H}), 3.29-3.20(\mathrm{~m}, 3 \mathrm{H}), 3.16-3.02(\mathrm{~m}, 4 \mathrm{H}), 2.98-2.78(\mathrm{~m}, 4 \mathrm{H}), 2.71-2.66$ $(\mathrm{m}, 1 \mathrm{H}), 2.53-2.40(\mathrm{~m}, 1 \mathrm{H}), 2.23(\mathrm{td}, J=14.0,5.2 \mathrm{~Hz}, 1 \mathrm{H}), 2.15(\mathrm{t}, J=7.4 \mathrm{~Hz}, 2 \mathrm{H}), 2.07-1.96(\mathrm{~m}$, 1H), $1.96-1.77(\mathrm{~m}, 2 \mathrm{H}), 1.68-1.21(\mathrm{~m}, 18 \mathrm{H}), 0.82-0.74(\mathrm{~m}, 1 \mathrm{H}) ;{ }^{19} \mathrm{~F}$ NMR (MeOD) $\delta-77.0$. HRMS (ESI-TOF) $m / z \mathrm{C}_{56} \mathrm{H}_{65} \mathrm{BF}_{2} \mathrm{~N}_{6} \mathrm{O}_{7} \mathrm{~S}[\mathrm{MH}]^{+}$calcd, 1013.4733; found, 1013.4731.

2-((1E,3E,5E)-5-(1-Ethyl-3,3-dimethyl-5-sulfoindolin-2-ylidene)penta-1,3-dien-1-yl)-1-(6-((6((6S,7R,7aR,12bS)-9-hydroxy-7-methoxy-3-methyl-1,2,3,4,5,6,7,7a-octahydro-4a,7-ethano-4,12methanobenzofuro[3,2-e]isoquinoline-6-carboxamido)hexyl)amino)-6-oxohexyl)-3,3-dimethyl-3Hindol-1-ium-5-sulfonate, 2,2,2-trifluoroacetate salt (3). Compound 11b (19.3 mg, $27.7 \mu \mathrm{mol})$ was dissolved in dry DMF $(200 \mu \mathrm{l})$. DIPEA (40 $\mu \mathrm{l}, 230 \mu \mathrm{mol}), \mathrm{Cy} 5(15 \mathrm{mg}, 22.8 \mu \mathrm{mol})$ and PyBOP (14.7 $\mathrm{mg}, 28.3 \mu \mathrm{mol})$ were added to this solution, pre-dissolved in dry DMF (200 $\mu \mathrm{L})$. The reaction mixture was left to stir under a nitrogen atmosphere for $1 \mathrm{~h}$ with the exclusion of light. The resulting solution was added to $\mathrm{MeOH}(1 \mathrm{~mL})$ and purified by reverse-phase prep HPLC (4-37\% buffer D in C) to give compound 3 as a blue solid after lypholization $(5.00 \mathrm{mg}, 18 \%) .{ }^{1} \mathrm{H}$ NMR (MeOD) $\delta_{\mathrm{HH}} 8.53-8.16(\mathrm{~m}$, 2H), 8.02-7.76 (m, 4H), $7.34(\mathrm{dd}, J=15.1,8.5 \mathrm{~Hz}, 2 \mathrm{H}), 6.85-6.58(\mathrm{~m}, 3 \mathrm{H}), 6.44-6.30(\mathrm{~m}, 2 \mathrm{H}), 4.58$ (s, 1H), 4.22-4.14 (m, 4H), $3.68(\mathrm{~d}, J=6.9 \mathrm{~Hz}, 1 \mathrm{H}), 3.40(\mathrm{~s}, 3 \mathrm{H}), 3.22-3.14(\mathrm{~m}, 6 \mathrm{H}), 3.00(\mathrm{~s}, 3 \mathrm{H})$, 2.97-2.71 (m, 2H), 2.67-2.50 (m, 1H), 2.47-2.28 (m, 1H), $2.18(\mathrm{t}, J=6.8 \mathrm{~Hz}, 2 \mathrm{H}), 1.99-1.64(\mathrm{~m}$, 20H), 1.51-1.26 (m, 16H), 0.83-0.74 (m, 1H); ${ }^{19} \mathrm{~F}$ NMR (MeOD) $\delta-77.3$. HRMS (ESI-TOF) $m / z$ $\mathrm{C}_{60} \mathrm{H}_{77} \mathrm{~N}_{5} \mathrm{O}_{11} \mathrm{~S}_{2}[\mathrm{MH}]^{+}$calcd, 1108.5134; found, 1108.5113.

(3R,6S, 7R,7aR,12bS)-9-hydroxy-7-methoxy-6-((6-(4-((6-methoxy-1,2,4,5-tetrazin-3yl)oxy)butanamido)hexyl)carbamoyl)-3-methyl-1,2,3,4,5,6,7,7a-octahydro-4a,7-ethano-4,12methanobenzofuro[3,2-e]isoquinolin-3-ium 2,2,2-trifluoroacetate (4). Compound 11 (132 mg, 189 $\mu \mathrm{mol})$ was dissolved in dry DMF $(1 \mathrm{~mL})$. DIPEA $(150 \mu \mathrm{l}, 861 \mu \mathrm{mol})$ and $19(91.3 \mathrm{mg}, 293 \mu \mathrm{mol})$ were added and the reaction mixture left to stir under a nitrogen atmosphere for $1 \mathrm{~h}$. 1:3 $(v / v)$ 
IPA: $\mathrm{CHCl}_{3}(50 \mathrm{~mL})$ was then added and the mixture washed with $\mathrm{H}_{2} \mathrm{O}(3 \times 50 \mathrm{~mL})$ and brine $(30 \mathrm{~mL})$. The organic layer was dried with $\mathrm{MgSO}_{4}$ and the solvent removed in vacuo. The resulting oil was purified by reverse-phase prep HPLC (5-100\% buffer D in C). The aqueous phase was washed with 3 $\times 100 \mathrm{~mL} \mathrm{1:3(v/v)} \mathrm{IPA/CHCl} 3$ and lyophilized to give compound 4 as a pink solid $(11.2 \mathrm{mg}, 18 \%) .{ }^{1} \mathrm{H}$ NMR (MeOD) $\delta_{\mathrm{HH}} 6.74(\mathrm{~d}, J=8.1 \mathrm{~Hz}, 1 \mathrm{H}), 6.66(\mathrm{~d}, J=8.1 \mathrm{~Hz}, 1 \mathrm{H}), 4.60-4.56(\mathrm{~m}, 3 \mathrm{H}), 4.21(\mathrm{~s}, 3 \mathrm{H})$, $3.70(\mathrm{~d}, J=7.1 \mathrm{~Hz}, 1 \mathrm{H}), 3.42(\mathrm{~s}, 3 \mathrm{H}), 3.20-3.08(\mathrm{~m}, 5 \mathrm{H}), 2.99-2.89(\mathrm{~m}, 4 \mathrm{H}), 2.72(\mathrm{dd}, J=10.0,5.6$ $\mathrm{Hz}, 1 \mathrm{H}), 2.53-2.40(\mathrm{~m}, 3 \mathrm{H}), 2.32-2.15(\mathrm{~m}, 3 \mathrm{H}), 2.10-1.97(\mathrm{~m}, 2 \mathrm{H}), 1.91-1.83(\mathrm{~m}, 1 \mathrm{H}), 1.57-1.42(\mathrm{~m}$, $6 \mathrm{H}), 1.42-1.28(\mathrm{~m}, 6 \mathrm{H}), 0.89-0.80(\mathrm{~m}, 1 \mathrm{H}) ;{ }^{19} \mathrm{~F}$ NMR (MeOD) $\delta-77.2 . \quad$ HRMS (ESI-TOF) $m / z$ $\mathrm{C}_{34} \mathrm{H}_{47} \mathrm{~N}_{7} \mathrm{O}_{7}[\mathrm{MH}]^{+}$calcd, 665.3537; found, 665.3559.

(4R,7aR,12bS)-9-((tert-Butyldimethylsilyl)oxy)-7-methoxy-3-methyl-2,3,4,7a-tetrahydro-1H-4,12methanobenzofuro[3,2-e]isoquinoline (6). Compound 5 (400 mg, $1.35 \mathrm{mmol}$ ), imidazole (362.6 mg, $5.33 \mathrm{mmol})$ and tert-butyldimethylsilyl chloride $(533 \mathrm{mg}, 3.54 \mathrm{mmol})$ were dissolved in dry DMF (1 $\mathrm{mL}$ ). The dark brown solution was allowed to stir for approximately $1 \mathrm{~min}$ under a nitrogen atmosphere, after which the mixture solidified, indicating reaction completion. The solid was dissolved in $\mathrm{H}_{2} \mathrm{O}(100 \mathrm{~mL})$ and $\mathrm{Et}_{2} \mathrm{O}(100 \mathrm{~mL})$ and washed with more $\mathrm{Et}_{2} \mathrm{O}(3 \times 100 \mathrm{~mL})$. The organic layers were then washed with brine $(100 \mathrm{~mL})$, dried with $\mathrm{Na}_{2} \mathrm{SO}_{4}$ and the solvent removed in vacuo. The brown residue was purified by column chromatography (1\% TEA in $\left.\mathrm{CHCl}_{3}\right)$ to give compound $\mathbf{6}$ as a slightly brown oil which solidifies on standing $(83 \%, 458.5 \mathrm{mg})$. All characterization data were in agreement with Klein et al. ${ }^{69}$

(4R,7R,7aR,12bS,14S)-Methyl-9-((tert-butyldimethylsilyl)oxy)-7-methoxy-3-methyl-1,2,3,4,7,7ahexahydro-7,4a-ethano-4,12-methanobenzofuro[3,2-e]isoquinoline-14-carboxylate (7). Compound 6 $(5.00 \mathrm{~g}, 12.2 \mathrm{mmol})$ was dissolved in methyl acrylate $(10 \mathrm{~mL}, 111 \mathrm{mmol})$ and heated by microwave irradiation to $130{ }^{\circ} \mathrm{C}$ for $3 \mathrm{~h}$. The remaining methyl acrylate was removed in vacuo and the resulting oil purified by column chromatography and recrystallized from minimal hot methanol to give 
compound 7 as faint yellow crystals $(69 \%, 4.22 \mathrm{~g}) .{ }^{1} \mathrm{H}$ NMR $(\mathrm{MeOD}) \delta_{\mathrm{HH}} 6.50(\mathrm{~d}, J=8.1 \mathrm{~Hz}, 1 \mathrm{H})$, $6.46(\mathrm{~d}, J=8.1 \mathrm{~Hz}, 1 \mathrm{H}), 5.58(\mathrm{~d}, J=8.9 \mathrm{~Hz}, 1 \mathrm{H}), 5.51(\mathrm{~d}, J=8.8 \mathrm{~Hz}, 1 \mathrm{H}), 4.68(\mathrm{~d}, J=1.2 \mathrm{~Hz}, 1 \mathrm{H})$, $3.63(\mathrm{~s}, 3 \mathrm{H}), 3.55(\mathrm{~s}, 3 \mathrm{H}), 3.22(\mathrm{dd}, J=12.5,6.1 \mathrm{~Hz}, 2 \mathrm{H}), 3.09-2.88(\mathrm{~m}, 2 \mathrm{H}), 2.58-2.39(\mathrm{~m}, 3 \mathrm{H}), 2.36$ (s, 3H), $2.04(\mathrm{td}, J=12.8,5.6 \mathrm{~Hz}, 1 \mathrm{H}), 1.77(\mathrm{dd}, J=13.3,2.3 \mathrm{~Hz}, 1 \mathrm{H}), 1.42(\mathrm{dd}, J=11.5,5.1 \mathrm{~Hz}, 1 \mathrm{H})$, $0.97(\mathrm{~s}, 9 \mathrm{H}), 0.15(\mathrm{~s}, 3 \mathrm{H}), 0.13(\mathrm{~s}, 3 \mathrm{H}) ;{ }^{13} \mathrm{C}$ NMR $(\mathrm{MeOD}) \delta_{\mathrm{CH}} 175.5,151.1,138.0,136.6,135.6$, $130.3,128.0,122.4,120.7,93.0,82.3,61.4,52.3,52.3,49.9,46.7,44.2,43.8,43.5,34.4,31.6,26.2$, 23.4, 19.2, -4.3. LC-MS ESI ${ }^{+} m / z[\mathrm{M}+\mathrm{H}]=498.3$.

tert-Butyl-(6-((4R,7R,7aR,12bS,14S)-9-hydroxy-7-methoxy-3-methyl-1,2,3,4,7,7a-hexahydro7,4a-ethano-4,12-methanobenzofuro[3,2-e]isoquinoline-14-carboxamido)hexyl)carbamate Compound 7 (2.72 g, $5.47 \mathrm{mmol})$ was dissolved in THF (30 mL) and $1 \mathrm{M} \mathrm{LiOH} \mathrm{(30} \mathrm{mL)} \mathrm{and} \mathrm{left} \mathrm{to}$ stir for $14 \mathrm{~h}$. The solution was neutralized with $5 \mathrm{M} \mathrm{HCl}(6 \mathrm{~mL})$, producing a precipitate. The solvent was removed in vacuo. HOBt $(1.58 \mathrm{~g}, 11.7 \mathrm{mmol})$, compound 8 (2.62 g, $12.1 \mathrm{mmol})$ and the solid residue were then dissolved in dry DMF (25 mL). DIPEA (4.8 mL, $27.6 \mathrm{mmol})$ and EDC.HCl $(2.37 \mathrm{~g}$, $12.4 \mathrm{mmol})$ were dissolved in dry DMF (25 mL) and added via syringe. The reaction was allowed to stir at room temperature under nitrogen gas for $14 \mathrm{~h}$. The solvent was removed in vacuo, and the residue taken up in $\mathrm{H}_{2} \mathrm{O}(250 \mathrm{~mL})$ and $\mathrm{Et}_{2} \mathrm{O}(250 \mathrm{~mL})$. These layers were separated and the aqueous layer was washed with more $\mathrm{Et}_{2} \mathrm{O}(3 \times 150 \mathrm{~mL})$. All organic layers were combined and dried with $\mathrm{Na}_{2} \mathrm{SO}_{4}$ and the solvent removed in vacuo. The resulting oil was purified by column chromatography (0-2\% $\mathrm{MeOH}$ in $\left.\mathrm{CHCl}_{3}\right)$ and the relevant fractions concentrated to dryness in vacuo to give compound 8 as a pale yellow solid $(44 \%, 1.37 \mathrm{~g}) .{ }^{1} \mathrm{H}$ NMR $\left(\mathrm{CDCl}_{3}\right) \delta_{\mathrm{HH}} 6.60(\mathrm{~d}, J=8.1 \mathrm{~Hz}, 1 \mathrm{H}), 6.47(\mathrm{~d}, J=8.1$ $\mathrm{Hz}, 1 \mathrm{H}), 6.13-6.08(\mathrm{~m}, 1 \mathrm{H}), 5.83(\mathrm{~d}, J=8.8 \mathrm{~Hz}, 1 \mathrm{H}), 5.54(\mathrm{~d}, J=8.8 \mathrm{~Hz}, 1 \mathrm{H}), 4.57$ (bs, $1 \mathrm{H}), 4.54(\mathrm{~d}, J$ $=1.0 \mathrm{~Hz}, 1 \mathrm{H}), 3.57(\mathrm{~s}, 3 \mathrm{H}), 3.31-3.14(\mathrm{~m}, 4 \mathrm{H}), 3.12-3.00(\mathrm{~m}, 3 \mathrm{H}), 2.61(\mathrm{dd}, J=9.4,6.3 \mathrm{~Hz}, 1 \mathrm{H}), 2.52$ $(\mathrm{dd}, J=11.8,5.0 \mathrm{~Hz}, 1 \mathrm{H}), 2.44-2.28(\mathrm{~m}, 5 \mathrm{H}), 2.04-1.88(\mathrm{~m}, 1 \mathrm{H}), 1.81(\mathrm{dd}, J=13.0,2.4 \mathrm{~Hz}, 1 \mathrm{H})$, $1.52-1.38(\mathrm{~m}, 15 \mathrm{H}), 1.33-1.26(\mathrm{~m}, 4 \mathrm{H}) ;{ }^{13} \mathrm{C} \mathrm{NMR}\left(\mathrm{CDCl}_{3}\right) \delta_{\mathrm{CH}} 172.6,156.2,146.7,138.0,137.0$, 
$134.01,127.5,125.8,120.0,116.7,94.3,80.7,79.2,60.1,52.8,47.5,45.6,44.6,43.6,43.2,40.4,39.4$, 33.3, 31.2, 30.1, 29.5, 28.5, 26.4, 26.3, 22.6. HRMS (ESI-TOF) $m / z \mathrm{C}_{32} \mathrm{H}_{45} \mathrm{~N}_{3} \mathrm{O}_{6}[\mathrm{MH}]^{+}$calcd, 568.3381; found, 568.3370.

$(3 R, 4 R, 7 R, 7 a R, 12 b S, 14 S)$-14-((6-ammoniohexyl)carbamoyl)-9-hydroxy-7-methoxy-3-methyl-

1,2,3,4,7,7a-hexahydro-7,4a-ethano-4,12-methanobenzofuro[3,2-e]isoquinolin-3-ium chloride (9).

Compound 8 (317 mg, $0.558 \mathrm{mmol})$ was dissolved in $4 \mathrm{M} \mathrm{HCl}$ in dioxane $(5 \mathrm{~mL})$ and allowed to stir for $1 \mathrm{~h}$. The reaction mixture was then neutralized with sat. $\mathrm{NaHCO}_{3}$, the solvent rmeoved in vacuo and the remaining residue purified by column chromatography (89:10:1 $\left.\mathrm{CHCl}_{3}: \mathrm{MeOH}: \mathrm{NH}_{4} \mathrm{OH}\right)$. After concentrating the relevant fractions in vacuo, the resulting oil was dissolved in $1 \mathrm{M} \mathrm{HCl}(20 \mathrm{~mL})$ and lyophilized to give compound 9 (bis- $\mathrm{HCl}$ salt) as a pale orange solid $\left(39 \%, 118 \mathrm{mg}\right.$ ). ${ }^{1} \mathrm{H}$ NMR (MeOD) $\delta_{\mathrm{HH}} 6.61(\mathrm{~d}, J=8.1 \mathrm{~Hz}, 1 \mathrm{H}), 6.57(\mathrm{~d}, J=8.2 \mathrm{~Hz}, 1 \mathrm{H}), 5.87(\mathrm{~d}, J=8.6 \mathrm{~Hz}, 1 \mathrm{H}), 5.56(\mathrm{~d}, J=$ $8.8 \mathrm{~Hz}, 1 \mathrm{H}), 4.75(\mathrm{~s}, 1 \mathrm{H}), 4.17(\mathrm{~d}, J=4.5 \mathrm{~Hz}, 1 \mathrm{H}), 3.60(\mathrm{~s}, 3 \mathrm{H}), 3.46(\mathrm{t}, J=18.4 \mathrm{~Hz}, 1 \mathrm{H}), 3.37(\mathrm{t}, J=$ $8.3 \mathrm{~Hz}, 1 \mathrm{H}), 3.27-3.17(\mathrm{~m}, 2 \mathrm{H}), 3.15-3.10(\mathrm{~m}, 2 \mathrm{H}), 3.05(\mathrm{~s}, 3 \mathrm{H}), 3.01-2.98(\mathrm{~m}, 1 \mathrm{H}), 2.93(\mathrm{t}, J=7.2$ $\mathrm{Hz}, 3 \mathrm{H}), 2.34$ (t, $J=11.8 \mathrm{~Hz}, 1 \mathrm{H}), 2.12(\mathrm{~d}, J=12.9 \mathrm{~Hz}, 1 \mathrm{H}), 1.74-1.60(\mathrm{~m}, 3 \mathrm{H}), 1.57-1.49(\mathrm{~m}, 2 \mathrm{H})$, $1.45-1.35(\mathrm{~m}, 4 \mathrm{H}) ;{ }^{13} \mathrm{C}$ NMR $(\mathrm{MeOD}) \delta_{\mathrm{CH}} 173.8,148.6,140.7,133.5,133.0,128.7,124.3,121.4$, $118.9,93.7,81.6,63.7,53.5,48.3,47.4,44.9,43.9,42.9,40.6,40.1,31.5,31.3,30.1,28.4,27.0,26.9$, 25.7. HRMS (ESI-TOF) $m / z \mathrm{C}_{27} \mathrm{H}_{37} \mathrm{~N}_{3} \mathrm{O}_{4}$ [MH] ${ }^{+}$calcd, 468.2857; found, 468.2873. tert-Butyl-(6-((4R,6S,7R,7aR,12bS)-9-hydroxy-7-methoxy-3-methyl-1,2,3,4,5,6,7,7a-octahydro4a,7-ethano-4,12-methanobenzofuro[3,2-e]isoquinoline-6-carboxamido)hexyl)carbamate

(10).

Compound 8 (200.7 mg, $0.354 \mathrm{mmol})$ was dissolved in ethanol $(10 \mathrm{~mL})$ and passed through a H-cube apparatus under the following conditions: 10 bar pressure, $25^{\circ} \mathrm{C}, 1 \mathrm{~mL} \mathrm{~min}{ }^{-1}$ flow rate. After $2 \mathrm{~h}$, the reaction was complete as indicated by LCMS. The solvent was removed in vacuo to give compound $\mathbf{1 0}$ as a white solid $(86 \%, 174 \mathrm{mg}) .{ }^{1} \mathrm{H}$ NMR $(\mathrm{MeOD}) \delta_{\mathrm{HH}} 6.74(\mathrm{~d}, J=8.1 \mathrm{~Hz}, 1 \mathrm{H}), 6.65(\mathrm{~d}, J=8.1 \mathrm{~Hz}$, 1H), $4.58(\mathrm{dd}, J=6.6,2.0 \mathrm{~Hz}, 1 \mathrm{H}), 3.69(\mathrm{~d}, J=6.9 \mathrm{~Hz}, 1 \mathrm{H}), 3.49-3.33(\mathrm{~m}, 4 \mathrm{H}), 3.30-3.23(\mathrm{~m}, 2 \mathrm{H})$, 
3.18-3.06 (m, 2H), 3.06-2.98 (m, 2H), 2.98-2.83 (m, 4H), 2.80-2.68 (m, 1H), 2.59-2.47 (m, 1H), 2.31 $(\mathrm{td}, J=14.1,5.4 \mathrm{~Hz}, 1 \mathrm{H}), 2.01(\mathrm{ddd}, J=17.9,13.9,4.6 \mathrm{~Hz}, 2 \mathrm{H}), 1.95-1.86(\mathrm{~m}, 1 \mathrm{H}), 1.73-1.21(\mathrm{~m}$, $19 \mathrm{H}), 0.82(\mathrm{dd}, J=17.5,7.7 \mathrm{~Hz}, 1 \mathrm{H}) ;{ }^{13} \mathrm{C}$ NMR $(\mathrm{MeOD}) \delta_{\mathrm{CH}} 174.0,158.6,147.5,140.8,131.1,124.3$, $121.2,119.4,92.7,79.8,77.0,64.8,52.2,47.7,45.4,44.4,42.6,41.2,40.5,37.1,33.1,30.9,30.5,30.4$, 29.7, 28.8, 27.5, 25.2, 19.0. HRMS (ESI-TOF) $\mathrm{m} / \mathrm{z}_{32} \mathrm{C}_{32} \mathrm{H}_{47} \mathrm{~N}_{3} \mathrm{O}_{6}[\mathrm{MH}]^{+}$calcd, 570.3538; found, 570.3538.

(4R,4aS,6S,7R,7aR,12bS)-6-((6-Ammoniohexyl)carbamoyl)-9-hydroxy-7-methoxy-3-methyl1,2,3,4,5,6,7,7a-octahydro-4a,7-ethano-4,12-methanobenzofuro[3,2-e]isoquinolin-3-ium chloride (11a). Compound 8 (641 mg, $1.13 \mathrm{mmol})$ was dissolved in ethanol $(30 \mathrm{~mL})$ and run through the $\mathrm{H}$ cube apparatus under the following conditions: 10 bar pressure, $25^{\circ} \mathrm{C}, 1 \mathrm{~mL} \mathrm{~min}^{-1}$ flow rate. After 10 $\mathrm{h}$, the reaction was complete as indicated by LCMS. The solvent was removed in vacuo and purified by column chromatography $\left(6-8 \% \mathrm{MeOH}\right.$ in $\left.\mathrm{CHCl}_{3}\right)$. The relevant fractions were evaporated to dryness. $4 \mathrm{M} \mathrm{HCl}(30 \mathrm{~mL})$ was added and this solution was allowed to stir for $30 \mathrm{~min}$. The solution was lyophilized to give compound $\mathbf{1 1}$ as a green solid in the bis- $\mathrm{HCl}$ salt form $(29 \%, 174 \mathrm{mg}) .{ }^{1} \mathrm{H}$ NMR (1:1 MeOD:D $2 \mathrm{O}) \delta_{\mathrm{HH}} 6.77(\mathrm{~d}, J=7.9 \mathrm{~Hz}, 1 \mathrm{H}), 6.70(\mathrm{~d}, J=7.9 \mathrm{~Hz}, 1 \mathrm{H}), 4.71(\mathrm{~s}, 1 \mathrm{H}), 3.69(\mathrm{~d}, J=$ $5.6 \mathrm{~Hz}, 1 \mathrm{H}), 3.39(\mathrm{~s}, 3 \mathrm{H}), 3.33-3.23(\mathrm{~m}, 3 \mathrm{H}), 3.13-2.99(\mathrm{~m}, 2 \mathrm{H}), 2.94(\mathrm{~s}, 7 \mathrm{H}), 2.63(\mathrm{t}, J=10.2 \mathrm{~Hz}$, 1H), $2.34(\mathrm{t}, J=11.7 \mathrm{~Hz}, 1 \mathrm{H}), 1.98-1.82(\mathrm{~m}, 3 \mathrm{H}), 1.64(\mathrm{bs}, 2 \mathrm{H}), 1.54-1.45(\mathrm{~m}, 3 \mathrm{H}), 1.36(\mathrm{bs}, 4 \mathrm{H})$, $1.30-1.24(\mathrm{~m}, 1 \mathrm{H}), 0.76(\mathrm{t}, J=10.8 \mathrm{~Hz}, 1 \mathrm{H}) ;{ }^{13} \mathrm{C}$ NMR $\left(1: 1 \mathrm{MeOD}: \mathrm{D}_{2} \mathrm{O}\right) \delta_{\mathrm{CH}} 174.0,146.7,139.4$, $130.9,124.9,121.5,119.1,90.3,77.4,64.1,51.8,47.3,44.8,43.0,42.8,40.4,40.2,36.7,32.5,30.53$, 29.4, 29.2, 27.8, 26.6, 26.4, 25.0, 19.5. HRMS (ESI-TOF) $m / z \mathrm{C}_{27} \mathrm{H}_{39} \mathrm{~N}_{3} \mathrm{O}_{4}[\mathrm{MH}]^{+}$calcd, 470.3013; found, 470.3011 .

(3R,4aS,7R,7aR, 12bS)-6-((6-ammoniohexyl)carbamoyl)-9-hydroxy-7-methoxy-3-methyl1,2,3,4,5,6,7,7a-octahydro-4a,7-ethano-4,12-methanobenzofuro[3,2-e]isoquinolin-3-ium 2,2,2trifluoroacetate $\mathbf{( 1 1 b )}$ 
Compound $10(181 \mathrm{mg}, 0.317 \mathrm{mmol})$ was added to a 1:1 solution of water and trifluoroacetic acid (2 $\mathrm{mL}$ ) and left to stir at room temperature for 6 hours. The resulting solution was lyophilized and the solid purified by reverse-phase prep HPLC (5-100\% buffer D in C) to give compound 11b as a white solid (76 mg, 34\%). ${ }^{1} \mathrm{H}$ NMR (MeOD) $\delta_{\mathrm{HH}} 6.74(\mathrm{~d}, J=8.1 \mathrm{~Hz}, 1 \mathrm{H}), 6.66(\mathrm{~d}, J=8.1 \mathrm{~Hz}, 1 \mathrm{H}), 4.60(\mathrm{~d}, J=1.9$ Hz, 1H), $3.69(\mathrm{~d}, J=6.8 \mathrm{~Hz}, 1 \mathrm{H}), 3.42(\mathrm{~s}, 3 \mathrm{H}), 3.37-3.32(\mathrm{~m}, 2 \mathrm{H}), 3.30-3.25(\mathrm{~m}, 1 \mathrm{H}), 3.14-3.07(\mathrm{~m}, 2 \mathrm{H}), 2.99-$ $2.88(\mathrm{~m}, 6 \mathrm{H}), 2.81-2.73(\mathrm{~m}, 1 \mathrm{H}), 2.63-2.52(\mathrm{~m}, 1 \mathrm{H}), 2.33(\mathrm{td}, J=14.1,5.3 \mathrm{~Hz}, 1 \mathrm{H}), 2.11-1.81(\mathrm{~m}, 3 \mathrm{H}), 1.73-$ $1.60(\mathrm{~m}, 2 \mathrm{H}), 1.56-1.49(\mathrm{~m}, 3 \mathrm{H}), 1.45-1.37(\mathrm{~m}, 5 \mathrm{H}), 0.86-0.80(\mathrm{~m}, 1 \mathrm{H}) .{ }^{19} \mathrm{~F}$ NMR (MeOD) $\delta$ - 76.8, 77.4.

tert-Butyl(6-(2,5-dioxo-2,5-dihydro-1H-pyrrol-1-yl)hexyl)carbamate (12). Compound 3 (536 $\mathrm{mg}, 2.48 \mathrm{mmol})$ was added to THF (9 mL) and sat. $\mathrm{NaHCO}_{3}(15 \mathrm{~mL})$ and left to stir at $0{ }^{\circ} \mathrm{C}$ for $10 \mathrm{~min}$. $N$-(Ethoxycarbonyl)maleimide $(386 \mathrm{mg}, 2.28 \mathrm{mmol})$ dissolved in more THF $(6 \mathrm{~mL})$ and then slowly added over $5 \mathrm{~min}$. The mixture was allowed to stir for $15 \mathrm{~min}$, after which time a further $30 \mathrm{~mL}$ of THF was added. This mixture was allowed to stir for another $45 \mathrm{~min}$ and cool to room temperature. The mixture was then extracted with EtOAc $(3 \times 60 \mathrm{~mL})$, washed with brine $(120 \mathrm{~mL})$, dried with $\mathrm{Na}_{2} \mathrm{SO}_{4}$ and the solvent removed in vacuo. The residual solid was purified by column chromatography (EtOAc) to yield compound 12 as a white solid $(89 \%, 602 \mathrm{mg}) .{ }^{1} \mathrm{H}$ NMR and ${ }^{13} \mathrm{C}$ NMR spectral data were in agreement with Kobayashi et al. ${ }^{68}$

tert-Butyl (6-((1R,4aS,9aR,10R,10aS,13aR)-8-hydroxy-10-methoxy-2-methyl-11,13-dioxo1,2,3,4,9a,10,10a,11,13,13a-decahydro-12H-10,13b-etheno-1,5-methanobenzofuro[3,2-e]pyrrolo[3,4h]isoquinolin-12-yl)hexyl)carbamate (13). Oripavine (244 mg, $0.819 \mathrm{mmol})$ and compound 12 (276 $\mathrm{mg}, 0.933 \mathrm{mmol})$ were added to ethanol $(10 \mathrm{~mL})$ and refluxed for $5 \mathrm{~h}$. The solvent was removed in vacuo and the residual black oil purified by column chromatography (0-2\% $\mathrm{MeOH}$ in $\left.\mathrm{CHCl}_{3}\right)$. The relevant fractions were combined and the solvent evaporated in vacuo to give compound $\mathbf{1 3}$ as an offwhite solid $(52 \%, 255 \mathrm{mg}) .{ }^{1} \mathrm{H} \mathrm{NMR}\left(\mathrm{CDCl}_{3}\right) \delta_{\mathrm{HH}} 6.61(\mathrm{~d}, J=8.1 \mathrm{~Hz}, 1 \mathrm{H}), 6.47(\mathrm{~d}, J=8.1 \mathrm{~Hz}, 1 \mathrm{H})$, $5.65(\mathrm{~d}, J=8.7 \mathrm{~Hz}, 1 \mathrm{H}), 5.32(\mathrm{~d}, J=8.8 \mathrm{~Hz}, 1 \mathrm{H}), 4.62(\mathrm{~d}, J=1.1 \mathrm{~Hz}, 1 \mathrm{H}), 4.59(\mathrm{t}, J=5.7 \mathrm{~Hz}, 1 \mathrm{H})$, 
$4.17(\mathrm{~d}, J=7.9 \mathrm{~Hz}, 1 \mathrm{H}), 3.97(\mathrm{~d}, J=6.6 \mathrm{~Hz}, 1 \mathrm{H}), 3.66(\mathrm{~s}, 3 \mathrm{H}), 3.35(\mathrm{t}, J=7.1 \mathrm{~Hz}, 2 \mathrm{H}), 3.20(\mathrm{~d}, J=$ $18.7 \mathrm{~Hz}, 1 \mathrm{H}), 3.08-2.96(\mathrm{~m}, 3 \mathrm{H}), 2.59-2.52(\mathrm{~m}, 1 \mathrm{H}), 2.49-2.33(\mathrm{~m}, 5 \mathrm{H}), 1.99-1.78(\mathrm{~m}, 2 \mathrm{H}), 1.46-1.32$ $(\mathrm{m}, 13 \mathrm{H}), 1.26-1.12(\mathrm{~m}, 4 \mathrm{H}) ;{ }^{13} \mathrm{C} \mathrm{NMR}\left(\mathrm{CDCl}_{3}\right) \delta_{\mathrm{CH}} 177.5,174.3,156.1,146.6,138.2,133.7,132.6$, $128.6,127.0,120.4,117.3,90.6,80.8,79.2,57.1,51.5,48.1,45.2,45.2,43.3,42.2,41.2,40.4,38.8$, 33.4, 29.8, 28.5, 27.5, 26.3, 26.1, 22.6. HRMS (ESI-TOF) $m / z \mathrm{C}_{33} \mathrm{H}_{43} \mathrm{~N}_{3} \mathrm{O}_{7}[\mathrm{MH}]^{+}$calcd, 494.2649; found, 494.2668.

(1R,2S,4aS,9aR,10R,10aS,13aR)-12-(6-Ammoniohexyl)-8-hydroxy-10-methoxy-2-methyl-11,13dioxo-1,2,3,4,9a,10,10a,12,13,13a-decahydro-11H-10,13b-etheno-1,5-methanobenzofuro[3,2e]pyrrolo[3,4-h]isoquinolin-2-ium chloride (14). Compound 13 (203 mg, $0.343 \mathrm{mmol})$ was stirred in 4 $\mathrm{M} \mathrm{HCl}$ in dioxane $(5 \mathrm{~mL})$ for $1 \mathrm{~h}$ at room temperature. The reaction mixture was then neutralized with sat. $\mathrm{NaHCO}_{3}$ and the solvent removed in vacuo. The residue was purified by column chromatography (84:10:1 $\left.\mathrm{CHCl}_{3}: \mathrm{MeOH}: \mathrm{NH}_{4} \mathrm{OH}\right)$ and the relevant fractions evaporated under reduced pressure. The remaining oil was dissolved in $1 \mathrm{M} \mathrm{HCl}(10 \mathrm{~mL})$ and lyophilized to give compound 14 (bis- $\mathrm{HCl}$ salt) as a pale orange solid $\left(167 \mathrm{mg}, 86{ }^{1} \mathrm{H}\right.$ NMR $(\mathrm{DMSO}) \delta_{\mathrm{HH}} 6.46(\mathrm{~d}, J=8.0 \mathrm{~Hz}, 1 \mathrm{H}), 6.40(\mathrm{~d}, J=8.1 \mathrm{~Hz}$, $1 \mathrm{H}), 5.47(\mathrm{~d}, J=8.7 \mathrm{~Hz}, 1 \mathrm{H}), 5.34(\mathrm{~d}, J=8.7 \mathrm{~Hz}, 1 \mathrm{H}), 4.76(\mathrm{~s}, 1 \mathrm{H}), 4.11(\mathrm{~d}, J=7.8 \mathrm{~Hz}, 1 \mathrm{H}), 3.81(\mathrm{~d}, J$ $=6.5 \mathrm{~Hz}, 1 \mathrm{H}), 3.53(\mathrm{~s}, 3 \mathrm{H}), 3.40(\mathrm{~d}, J=7.9 \mathrm{~Hz}, 1 \mathrm{H}), 3.24(\mathrm{t}, J=6.8 \mathrm{~Hz}, 2 \mathrm{H}), 3.09(\mathrm{~d}, J=18.5 \mathrm{~Hz}, 1 \mathrm{H})$, 2.53-2.43 (m, 4H), 2.37-2.22 (m, 4H), 2.11-1.96 (m, 1H), $1.70(\mathrm{~d}, J=11.3 \mathrm{~Hz}, 1 \mathrm{H}), 1.42-0.97(\mathrm{~m}$, $8 \mathrm{H}) ;{ }^{13} \mathrm{C}$ NMR $\left(d_{6}\right.$-DMSO) $\delta_{\mathrm{CH}} 177.4,174.2,146.5,138.6,133.5,132.7,128.7,125.7,119.6,116.8$, $88.2,80.5,56.6,50.4,47.2,44.7,44.6,43.0,42.1,41.3,40.4,37.7,32.8,32.5,27.1,26.0,25.9,21.7$. HRMS (ESI-TOF) $m / z \mathrm{C}_{28} \mathrm{H}_{35} \mathrm{~N}_{3} \mathrm{O}_{5}[\mathrm{MH}]^{+}$calcd, 494.2649; found, 494.2668.

3-(4-Hydroxybutoxy)-6-methoxy-s-tetrazine (17). 1,4-Butanediol (725 $\mu \mathrm{L}, 8.16 \mathrm{mmol}$ ) was slowly added to a stirred mixture of $60 \% \mathrm{NaH}(270 \mathrm{mg}, 6.75 \mathrm{mmol})$ in anhydrous THF (50 mL). The mixture was allowed to stir under an $\mathrm{N}_{2}$ atmosphere for 30 min. 3-Chloro-6-methoxy-s-tetrazine (795 $\mathrm{mg}, 5.44 \mathrm{mmol})$ was dissolved in anhydrous THF $(20 \mathrm{~mL})$ in a separate flask. Both of the 
aforementioned mixtures/solutions were cooled to $-78{ }^{\circ} \mathrm{C}$. The solution containing the 3-chloro-6methoxy-s-tetrazine was quickly poured into the alkoxide mixture. The resulting mixture was kept at $78{ }^{\circ} \mathrm{C}$ for $1 \mathrm{~h}$, then allowed to warm slowly to room temperature and stirred for a further $30 \mathrm{~min}$. The mixture was filtered and the retentate washed with dichloromethane. The filtrate was concentrated in vacuo and purified by column chromatography $\left(100 \% \mathrm{CHCl}_{3}\right)$ to give $\mathbf{1 8}$ as a red solid $(211 \mathrm{mg}, 19 \%)$. ${ }^{1} \mathrm{H}$ NMR and ${ }^{13} \mathrm{C}$ NMR spectral data were in agreement with Gong et al. ${ }^{52}$

4-((6-Methoxy-1,2,4,5-tetrazin-3-yl)oxy)butanoic acid (18). To a stirred solution of 17 (222 mg, $1.11 \mathrm{mmol})$ in $\mathrm{ACN}(10 \mathrm{ml})$ at $0{ }^{\circ} \mathrm{C}$ was added a solution of $\mathrm{CrO}_{3}(1.52 \mathrm{mg}, 15.2 \mu \mathrm{mol})$ and $\mathrm{H}_{5} \mathrm{IO}_{6}(650$ $\mathrm{mg}, 2.85 \mathrm{mmol})$ in $\mathrm{ACN}(14 \mathrm{~mL})$. The reaction mixture was stirred at $0{ }^{\circ} \mathrm{C}$ for $30 \mathrm{~min}$, then warmed to room temperature and stirred for further $30 \mathrm{~min}$. The solvent was then removed in vacuo and the residue taken up in EtOAc $(50 \mathrm{~mL})$, washed with half-saturated brine $(30 \mathrm{~mL})$, sodium bisulfite solution ( $1 \mathrm{~g} \mathrm{NaHSO}_{3}$ in $20 \mathrm{~mL} \mathrm{H} \mathrm{H}_{2} \mathrm{O}$ ) and brine again $(30 \mathrm{~mL})$, before being dried with $\mathrm{Na}_{2} \mathrm{SO}_{4}$ and the solvent removed in vacuo to give 18 as a pink solid $(238 \mathrm{mg}, 100 \%)$. ${ }^{1} \mathrm{H}$ NMR $(\mathrm{MeOD}) \delta_{\mathrm{HH}} 4.61(\mathrm{t}, J=$ $6.3 \mathrm{~Hz}, 2 \mathrm{H}), 4.21(\mathrm{~s}, 3 \mathrm{H}), 2.55(\mathrm{t}, J=7.3 \mathrm{~Hz}, 2 \mathrm{H}), 2.23-2.15(\mathrm{~m}, 2 \mathrm{H}) ;{ }^{13} \mathrm{C} \mathrm{NMR}(\mathrm{MeOD}) \delta_{\mathrm{CH}} 176.7$, $167.9,167.6,69.9,57.1,31.2,25.3$.

2,5-Dioxopyrrolidin-1-yl 4-((6-methoxy-1,2,4,5-tetrazin-3-yl)oxy)butanoate (19). To a stirred solution of $18(64.4 \mathrm{mg}, 0.301 \mathrm{mmol})$ in dry DCM $(3 \mathrm{~mL})$ at $0{ }^{\circ} \mathrm{C}$ was added $N$-hydroxysuccinimide (42.5 mg, $0.369 \mathrm{mmol})$ and dicyclohexylcarbodiimide $(89.7 \mathrm{mg}, 0.435 \mathrm{mmol})$. The reaction mixture was stirred at $0{ }^{\circ} \mathrm{C}$ for $30 \mathrm{~min}$, warmed to room temperature and stirred for a further $30 \mathrm{~min}$, then placed in the freezer at $-20^{\circ} \mathrm{C}$ for $2 \mathrm{~h}$. The mixture was then filtered, the collected precipitate washed with minimal cold DCM, and the filtrate concentrated to dryness in vacuo. The residue was purified via column chromatography (1:99 (v/v) MeOH:DCM) to give 19 as an impure pink oil (91 mg, 97\% recovery $\left(75 \% 19,25 \%\right.$ DCU by mass according to ${ }^{1} \mathrm{H}$ NMR). ${ }^{1} \mathrm{H}$ NMR $(\mathrm{MeOD}) \delta_{\mathrm{HH}} 4.66(\mathrm{t}, J=6.1$ $\mathrm{Hz}, 2 \mathrm{H}), 4.22(\mathrm{~s}, 3 \mathrm{H}), 2.93(\mathrm{t}, J=7.2 \mathrm{~Hz}, 2 \mathrm{H}), 2.83(\mathrm{~s}, 4 \mathrm{H}), 2.33(\mathrm{app}, J=6.6 \mathrm{~Hz}, 2 \mathrm{H})$. 
Pharmacology. Cell lines and transfection. FlpIn Chinese hamster ovary (CHO) cells (Invitrogen, Carlsbad, USA) were grown in Dulbecco's modified Eagle's medium (DMEM) supplemented with $5 \%$ fetal bovine serum and maintained at $37{ }^{\circ} \mathrm{C}$ in a humidified incubator containing 5\% $\mathrm{CO}_{2}$. The FlpIn $\mathrm{CHO}$ cells were transfected with the pOG44 vector encoding Flp recombinase and the pDEST vector containing the full coding sequence for the human mu-, delta- or kappa opioid receptors (hMOR, hDOR and hKOR, respectively) at a ratio of 9:1 using polyethylenimine as transfection reagent. At $24 \mathrm{~h}$-post transfection the cells were subcultured and the medium was supplemented with $700 \mu \mathrm{g} \mathrm{mL} \mathrm{m}^{-1}$ Hygromycin as selection agent. Cells were grown and maintained in DMEM containing $20 \mathrm{mM}$ HEPES, 5\% fetal bovine serum and $200 \mu \mathrm{g} \mathrm{mL} \mathrm{m}^{-1}$ Hygromycin- $\mathrm{B}$ at $37{ }^{\circ} \mathrm{C}$ in a humidified incubator containing $5 \% \mathrm{CO}_{2}$.

HEK 293 cells (ATCC, Middlesex, UK) were grown in Dulbecco's modified Eagle's medium (DMEM) supplemented with $10 \%$ fetal bovine serum and maintained at $37{ }^{\circ} \mathrm{C}$ in a humidified incubator containing 5\% $\mathrm{CO}_{2}$. The HEK 293 cells were transfected with the pcDNA3.1+ vector containing the full coding sequence for the human MOR (hMOR) or the hMOR-GFP fusion protein using Lipofectamine as transfection reagent according to manufacturer's instructions. $24 \mathrm{~h}$ post transfection the cells were subcultured and the medium was supplemented with $1 \mu \mathrm{g} \mathrm{mL}{ }^{-1} \mathrm{G} 418$ as selection agent. Cells were grown and maintained in DMEM containing, $10 \%$ fetal bovine serum and $100 \mu \mathrm{g} \mathrm{mL} L^{-1} \mathrm{G} 418$ at $37{ }^{\circ} \mathrm{C}$ in a humidified incubator containing $5 \% \mathrm{CO}_{2}$.

Preparation of FlpIN CHO cell membranes. Cells were harvested and centrifuged ( $300 \mathrm{x} \mathrm{g,} 3$ min). The resulting pellet was resuspended in assay buffer (20 mM HEPES, $100 \mathrm{mM} \mathrm{NaCl}, 6 \mathrm{mM}$ $\mathrm{MgCl}_{2}, 1 \mathrm{mM}$ EGTA, $1 \mathrm{mM}$ EDTA; $\mathrm{pH}$ 7.4), and the centrifugation procedure was repeated. The intact cell pellet was then resuspended in assay buffer and homogenized using a Polytron homogeniser for three 10 -sec intervals on the maximum setting, with 30 -sec periods on ice between each burst. The homogenate was made up to $30 \mathrm{~mL}$ and centrifuged $\left(1,000 \mathrm{~g}, 10 \mathrm{~min}, 25^{\circ} \mathrm{C}\right)$, the pellet discarded and 
the supernatant centrifuged at $30,000 \mathrm{~g}$ for $1 \mathrm{~h}$ at $4{ }^{\circ} \mathrm{C}$. The resulting pellet was resuspended in $5 \mathrm{~mL}$ assay buffer and the protein content determined. The homogenate was then separated into $1 \mathrm{~mL}$ aliquots and stored frozen at $-80{ }^{\circ} \mathrm{C}$ until required for binding assays.

$\left[{ }^{3}\right.$ H]Diphrenorphine binding assay. Cell membranes $(20 \mu \mathrm{g})$ were incubated with varying concentrations of test compound in binding buffer $(50 \mathrm{mM}$ Tris, $100 \mathrm{mM} \mathrm{NaCl}, 3 \mathrm{mM} \mathrm{MgCl}$; $\mathrm{pH}$ 7.4) containing $0.3 \mathrm{nM}$ of $\left[{ }^{3} \mathrm{H}\right]$ diprenorphine (Perkin Elmer) and $100 \mu \mathrm{M}$ GppNHp to a final volume of $0.5 \mathrm{~mL}$ and incubated at $25^{\circ} \mathrm{C}$ for $1 \mathrm{~h}$. Non-specific binding was determined in the presence of $100 \mu \mathrm{M}$ naloxone. Binding was terminated by fast flow filtration over GF/B membranes using a Brandel harvester followed by three washes with ice cold $0.9 \% \mathrm{NaCl}$. Bound radioactivity was measured in a Tri-Carb 2900TR liquid scintillation counter (Perkin Elmer).

ERK1/2 phosphorylation assay. FlpIn CHO cells stably expressing the three different OR subtypes were seeded into 96 -well plates at a density of 40,000 cells well ${ }^{-1}$. After $5-7 \mathrm{~h}$, cells were washed with phosphate-buffered saline (PBS) and incubated in serum-free DMEM overnight before assaying. Initially, time-course experiments were conducted at least twice for each ligand to determine their agonist activity and the time required to maximally promote ERK1/2 phosphorylation. Antagonist concentration-response curves were generated by preincubating the cells with increasing concentrations of each compound for $30 \mathrm{~min}$ at $37^{\circ} \mathrm{C}$ and stimulating the cells with an $\mathrm{EC}_{50}$ concentration of agonist (DAMGO for MOR, SNC-80 for DOR and ICI199441 for KOR) for 5 min at $37{ }^{\circ} \mathrm{C}$. Stimulation of the cells was terminated by removing the media and the addition of $100 \mu \mathrm{L}$ of SureFire lysis buffer (PerkinElmer, Waltham, USA) to each well. The plate was shaken for 5 min at RT before transferring 5 $\mu \mathrm{L}$ of the lysates to a white 384-well Proxiplate (PerkinElmer, Waltham, USA). $8 \mu \mathrm{L}$ of a 240:1440:7:7 mixture of Surefire activation buffer/Surefire reaction buffer/Alphascreen acceptor beads /Alphascreen donor beads was then added to the samples, before incubation in the dark at $37{ }^{\circ} \mathrm{C}$ for $1.5 \mathrm{~h}$. Plates were read using a Fusion-TM plate reader (PerkinElmer, Waltham, USA). Antagonist concentration- 
response curves were fitted to a Gaddum-Schild equation to describe competitive antagonism. ${ }^{59}$

Imaging Studies. HEK cells stably expressing a C-terminal tagged human MOR (HEK-MOR-GFP cells) were grown on Nunc Labtek 8 well plates in DMEM $+10 \%$ fetal calf serum (FCS) $+2 \mathrm{mM}$ glutamine. Cells were incubated in HEPES-buffered saline solution (HBSS) ${ }^{8}$ for 30 min at $37{ }^{\circ} \mathrm{C}$ in the presence or absence of naloxone $(1 \mu \mathrm{M})$ prior to addition of the fluorescent ligand at the indicated concentrations for $30 \mathrm{~min}$ at $37^{\circ} \mathrm{C}$.

Single-time point confocal images for HEK-MOR-GFP cells incubated with $\mathbf{2}$ and $\mathbf{3}$ were captured using on a Zeiss LSM Exciter or Zeiss LSM710 confocal microscope using a PlanApochromat $63 \times 1.3 N A$ oil-immersion objective lens. Samples were excited using a $633 \mathrm{~nm} \mathrm{HeNe}$ laser and an HFT458/543/633 dichroic with emission collected through a 650LP filter, with the emission pinhole set at $123 \mu \mathrm{m}$. GFP fluorescence was captured using a $488 \mathrm{~nm}$ Argon laser and 505530BP filter with the same pinhole size to give an equivalent slice depth. Attempts were made to image cells incubated with 1 and 4 using the same setup, but with a $405 \mathrm{~nm}$ diode laser, an MBS plate beam splitter and the emission pinhole set at $81 \mu \mathrm{m}$. All images comparative were obtained on the same day using the same microscope settings for laser power, offset and gain.

High-content analysis was carried out on an IX (ImageXpress) Ultra automated confocal plate reader (Molecular Devices, Sunnyvale, US). HEK-MOR cells were grown to confluency in 96-well plates over two days in DMEM + 10\% FCS, then simultaneously incubated $\left(30 \mathrm{~min}, 37{ }^{\circ} \mathrm{C}\right)$ in $\mathrm{HBSS}$ with increasing concentrations of unlabelled compounds and $50 \mathrm{nM}$ of $\mathbf{3}$ and four images per well captured (633 nm excitation, 650LP emission filter). The average total fluorescence intensity over the four images was determined using MetaXpress software (Molecular Devices LLC, Sunnyvale, CA). For the time course experiments, 2 and $\mathbf{3}$ were incubated at $37^{\circ} \mathrm{C}$ for $5,10,15,20$ and 30 min at 100 $\mathrm{nM}$ and $10 \mathrm{nM}$, respectively, with and without coincubation of naloxone $(1 \mu \mathrm{M})$. Half of the wells were washed once with HBSS prior to imaging. 
Competition curves were constructed using GraphPad Prism 6 by plotting the loss of fluorescence intensity as a function of competitive ligand concentration using the Cheng-Prusoff equation and the $\mathrm{A}_{2}$ value for 3 (49 $\mathrm{nM})$. All graphs represent the average of normalized measurements taken from three individual experiments performed in duplicate.

\section{- ASSOCIATED CONTENT}

Supporting Information. This material is available free of charge via the Internet at http://pubs.acs.org.

\section{- AUTHOR INFORMATION}

\section{Corresponding Authors}

*For P.J.S.: phone: +61 (0)3 9903 9542; E-mail: Peter.Scammells @ monash.edu. For B.G: phone: +61 (0)3 9903 9706; E-mail: Bim.Graham@monash.edu.

\section{Notes}

The author's declare no competing financial interest.

\section{- ACKNOWLEDGEMENTS}

We would like to thank Dr Gaik Orbell for her help and expertise in opiate chemistry, Prof. Graeme Henderson and Prof. Eamonn Kelly (University of Bristol) for kindly providing the human MOR-GFP cDNA, and the Australian Research Council (ARC), GSK Australia and Nottingham University for financial support. 


\section{- ABBREVIATIONS USED}

Boc, butyloxycarbonyl; BODIPY ${ }^{\mathrm{TM}}$, boron dipyrromethene difluoride; cAMP, cyclic adenosine monophosphate; $\mathrm{CHO}$, chinese hamster ovary; cns, central nervous system; Cy5, cyanine five; d, doublet; DAMGO, [D-Ala ${ }^{2}, \quad \mathrm{~N}-\mathrm{MePhe}^{4}$, Gly-ol]-enkephalin; DCM, dichloromethane; DCT, dichlorotetrazine; DIPEA, $N, N$-diisopropylethylamine; DMF, $N, N$-dimethylformamide; DMSO, dimethylsulfoxide; DOR, delta opioid receptor; EDC.HCl, 1-ethyl-3-(3dimethylaminopropyl)carbodiimide hydrochloride; ELISA, enzyme linked-immunosorbent assay; ESI electrospray ionization; FCS, fetal calf serum; FRET, fluorescence resonance energy transfer; GDP, guanosine diphosphate; GFP, green fluorescent protein; GPCR, G protein-coupled receptor; GTP, guanosine triphosphate; HBSS, HEPES buffered saline solution; HCTU, 2-(6-chloro-1H-benzotriazole1-yl)-1,1,3,3-tetramethylaminium hexafluorophosphate; HOBt, N-hydroxybenzotriazole; IX, ImageXpress; KOR, kappa opioid receptor; MOR, mu opioid receptor; OR, opioid receptor; NHS, $N$ hydroxysuccinimide; NO, Nitric Oxide; NOP, nociceptin opioid receptor; ppm, parts per million; PyBOP, benzotriazol-1-yl-oxytripyrrolidinophosphonium hexafluorophosphate; ORs, opioid receptors; SAR, structure-activity relationship; TBS, tert-butyldimethylsilyl; TFA, trifluoroacetic acid; THF, tetrahydrofuran; TICA, trichloroisocyanuric acid; XAC, xanthine amine congener; $\mu \mathrm{W}$, microwave. 


\section{REFERENCES}

(1) Thompson, A. A; Liu, W.; Chun, E.; Katritch, V.; Wu, H.; Vardy, E.; Huang, X.-P.; Trapella, C.; Guerrini, R.; Calo, G.; Roth, B. L.; Cherezov, V.; Stevens, R. C. Structure of the Nociceptin/orphanin FQ Receptor in Complex with a Peptide Mimetic. Nature 2012, 485, 395-399.

2) Zaveri, N.; Polgar, W. E.; Olsen, C. M.; Kelson, A B.; Grundt, P.; Lewis, J. W.; Toll, L. Characterization of Opiates, Neuroleptics, and Synthetic Analogs at ORL1 and Opioid Receptors. Euro. J. Pharmacol. 2001, 428, 29-36.

(3) Fredriksson, R.; Lagerström, M. C.; Lundin, L.-G.; Schiöth, H. B. The G-Protein-Coupled Receptors in the Human Genome Form Five Main Families. Phylogenetic Analysis, Paralogon Groups, and Fingerprints. Mol. Pharmacol. 2003, 63, 1256-1272.

(4) Mudge, A W.; Leeman, S. E.; Fischbach, G. D. Enkephalin Inhibits Release of Substance P from Sensory Neurons in Culture and Decreases Action Potential Duration. Proc. Natl. Acad. Sci. U.S.A. 1979, 76, 526-530.

(5) Rang and Dale's Pharmacology, 6th ed.; H. P. Rang; J. M. Ritter;, R. J. Flower, M. M. D., Ed.; Churchill Livingston: Philadelphia, USA., 2007.

(6) McDonald, J. Opioid Mechanisms and Opioid Drugs. Anaesth. Intens. Care Med. 2011, 12, $31-35$.

(7) Blakemore, P. R.; White, J. D. Morphine, the Proteus of Organic Molecules. Chem. Commun. 2002, 11, 1159-1168.

(8) Briddon, S. J.; Middleton, R. J.; Cordeaux, Y.; Flavin, F. M.; Weinstein, J. A.; George, M. W.; Kellam, B.; Hill, S. J. Quantitative Analysis of the Formation and Diffusion of A1-Adenosine Receptor-Antagonist Complexes in Single Living Cells. Proc. Natl. Acad. Sci. U.S.A. 2004, 101, 46734678.

(9) Leopoldo, M.; Lacivita, E.; Berardi, F.; Perrone, R. Developments in Fluorescent Probes for 
Receptor Research. Drug Discov. Today 2009, 14, 706-712.

(10) Arttamangkul, S.; Alvarez-Maubecin, V.; Thomas, G.; Williams, J. T.; Grandy, D. K. Binding and Internalization of Fluorescent Opioid Peptide Conjugates in Living Cells. Mol. Pharmacol. 2000, $58,1570-1580$.

(11) Macey, T. A; Ingram, S. L.; Bobeck, E. N.; Hegarty, D. M.; Aicher, S. A; Arttamangkul, S.; Morgan, M. M. Opioid Receptor Internalization Contributes to Dermorphin-Mediated Antinociception. Neuroscience 2010, 168, 543-550.

(12) Alvarez, V. A; Arttamangkul, S.; Dang, V.; Salem, A.; Whistler, J. L.; Von Zastrow, M.; Grandy, D. K.; Williams, J. T. Mu-Opioid Receptors: Ligand-Dependent Activation of Potassium Conductance, Desensitization, and Internalization. J. Neurosci. 2002, 22, 5769-5776.

(13) Arttamangkul, S.; Torrecilla, M.; Kobayashi, K.; Okano, H.; Williams, J. T. Separation of MuOpioid Receptor Desensitization and Internalization: Endogenous Receptors in Primary Neuronal Cultures. J. Neurosci. 2006, 26, 4118-4125.

(14) Vernall, A. J.; Stoddart, L. A; Briddon, S. J.; Ng, H. W.; Laughton, C. A; Doughty, S. W.; Hill, S. J.; Kellam, B. Conversion of a Non-Selective Adenosine Receptor Antagonist into A3-Selective High Affinity Fluorescent Probes Using Peptide-Based Linkers. Org. Biomol. Chem. 2013, 11, 56735682.

(15) Baker, J. G.; Middleton, R.; Adams, L.; May, L. T.; Briddon, S. J.; Kellam, B.; Hill, S. J. Influence of Fluorophore and Linker Composition on the Pharmacology of Fluorescent Adenosine A1 Receptor Ligands. Br. J. Pharmacol. 2010, 159, 772-786.

(16) Kuder, K.; Kieć-Kononowicz, K. Fluorescent GPCR Ligands as New Tools in Pharmacology. Curr. Med. Chem. 2008, 15, 2132-2143.

(17) Bonnet, D.; Riché, S.; Loison, S.; Dagher, R.; Frantz, M.-C.; Boudier, L.; Rahmeh, R.; Mouillac, B.; Haiech, J.; Hibert, M. Solid-Phase Organic Tagging Resins for Labeling Biomolecules by 
1,3-Dipolar Cycloaddition: Application to the Synthesis of a Fluorescent Non-Peptidic Vasopressin Receptor Ligand. Chemistry 2008, 14, 6247-6254.

(18) Fournie-Zaluski, M. C.; Gacel, G.; Roques, B. P.; Senault, B.; Lecomte, J. M.; Malfroy, B.;

Swerts, J. P.; Schwartz, J. C. Fluorescent Enkephalin Derivatives with Biological Activity. Biochem. Biophys. Res. Commun. 1978, 83, 300-305.

(19) Hazum, E.; Chang, K. J.; Shechter, Y.; Wilkinson, S.; Cuatrecasas, P. Fluorescent and PhotoAffinity Enkephalin Derivatives: Preparation and Interaction with Opiate Receptors. Biochem. Biophys. Res. Commun. 1979, 88, 841-846.

(20) Mihara, H.; Lee, S.; Shimohigashi, Y.; Aoyagi, H.; Kato, T.; Izumiya, N.; Costa, T. Delta and $\mathrm{Mu}$ Opiate Receptor Probes: Fluorescent Enkephalins with High Receptor Affinity and Specificity. FEBS Lett. 1985, 193, 35-38.

(21) Mihara, H.; Lee, S.; Shimohigashi, Y.; Aoyagi, H.; Kato, T.; Izumiya, N.; Costa, T. Tyr1Substituted and Fluorescent Pya1-Enkephalins Bind Strongly and Selectively to Mu and Delta Opiate Receptors. Biochem. Biophys. Res. Commun. 1986, 136, 1170-1176.

(22) Hazum, E.; Chang, K. J.; Cuatrecasas, P. Opiate (Enkephalin) Receptors of Neuroblastoma Cells: Occurrence in Clusters on the Cell Surface. Science 1979, 206, 1077-1079.

(23) Blanchard, S. G.; Chang, K. J.; Cuatrecasas, P. Visualization of Enkephalin Receptors by Image-Intensified Fluorescence Microscopy. Methods Enzymol. 1983, 103, 219-227.

(24) Zhou, M.; Nakatani, E.; Gronenberg, L. S.; Tokimoto, T.; J, M.; Hruby, V. J.; Roberts, A.; Lynch, R. M.; Ghosh, I.; Wirth, M. J. Peptide-Labeled Quantum Dots for Imaging GPCRs in Whole Cells and as Single Molecules. Synthesis 2007, 18, 323-332.

(25) Kolb, V. M.; Koman, A.; Terenius, L. Fluorescent Probes for Opioid Receptors. Life Sci. 1983, 33 Suppl 1 (c), 423-426.

(26) Archer, S.; Medzihradsky, F.; Seyed-Mozafari, A.; Emmerson, P. J. Synthesis and 
Characterization of 7-Nitrobenzo-2-Oxa-1,3-Diazole (NBD)-Labeled Fluorescent Opioids. Biochem. Pharmacol. 1992, 43, 301-306.

(27) Emmerson, P. J.; Archer, S.; El-hamouly, W.; Mansour, A. Synthesis and Characterization of 4 , 4-Difluoro-4-Bora- Ligands for the Mu Opioid Receptor. Science. 1997, 54, 1315-1322.

(28) Chang, a C.; Chao, C. C.; Takemori, A E.; Gekker, G.; Hu, S.; Peterson, P. K.; Portoghese, P. S. Arylacetamide-Derived Fluorescent Probes: Synthesis, Biological Evaluation, and Direct Fluorescent Labeling of Kappa Opioid Receptors in Mouse Microglial Cells. J. Med. Chem. 1996, 39, $1729-1735$.

(29) Gonçalves, M. S. T. Fluorescent Labeling of Biomolecules with Organic Probes. Chem. Rev. 2009, 109, 190-212.

(30) Pergolizzi, J.; Aloisi, A. M.; Dahan, A.; Filitz, J.; Langford, R.; Likar, R.; Mercadante, S.; Morlion, B.; Raffa, R. B.; Sabatowski, R.; Sacerdote, P.; Torres, L. M.; Weinbroum, A. A. Current Knowledge of Buprenorphine and Its Unique Pharmacological Profile. Pain Pr. 2010, 10, 428-450.

(31) IUPHAR-Buprenorphine http://www.iuphardb.org/DATABASE/LigandDisplayForward?tab=biology\&ligandId=1670 (accessed Mar 24, 2013).

(32) Manglik, A.; Kruse, A. C.; Kobilka, T. S.; Thian, F. S.; Mathiesen, J. M.; Sunahara, R. K.; Pardo, L.; Weis, W. I.; Kobilka, B. K.; Granier, S. Crystal Structure of the $\mu$-Opioid Receptor Bound to a Morphinan Antagonist. Nature 2012, 485, 321-326.

(33) Mignat, C.; Wille, U.; Ziegler, A. Affinity Profiles of Morphine, Codeine, Dihydrocodeine and Their Glucuronides at Opioid Receptor Subtypes. Life Sci. 1995, 56, 793-799.

(34) Raynor, K.; Kong, H.; Chen, Y.; Yasuda, K.; Yu, L. Pharmacological Characterization of the Cloned Kappa-, Delta-, and Mu-Opioid Receptors. Mol. Pharmacol. 1994, 45, 330-334.

(35) Aceto, M. D.; Harris, L. S.; Negus, S. S.; Banks, M. L.; Hughes, L. D.; Akgün, E.; Portoghese, P. S. MDAN-21: A Bivalent Opioid Ligand Containing Mu-Agonist and Delta-Antagonist 
Pharmacophores and Its Effects in Rhesus Monkeys. Int. J. Med. Chem. 2012, 2012, 1-6.

(36) Akgün, E.; Javed, M. I.; Lunzer, M. M.; Smeester, B. A; Beitz, A. J.; Portoghese, P. S. Ligands That Interact with Putative MOR-mGluR5 Heteromer in Mice with Inflammatory Pain Produce Potent Antinociception. Proc. Natl. Acad. Sci. U. S. A. 2013, 110, 11595-11599.

(37) Daniels, D. J.; Lenard, N. R.; Etienne, C. L.; Law, P.-Y.; Roerig, S. C.; Portoghese, P. S. Opioid-Induced Tolerance and Dependence in Mice Is Modulated by the Distance between Pharmacophores in a Bivalent Ligand Series. Proc. Natl. Acad. Sci. U.S.A. 2005, 102, 19208-19213.

(38) Le Naour, M.; Lunzer, M. M.; Powers, M. D.; Kalyuzhny, A. E.; Benneyworth, M. A;

Thomas, M. J.; Portoghese, P. S. Putative Kappa Opioid Heteromers as Targets for Developing Analgesics Free of Adverse Effects. J. Med. Chem. 2014, 57, 6383-6392.

(39) Le Naour, M.; Akgün, E.; Yekkirala, A.; Lunzer, M. M.; Powers, M. D.; Kalyuzhny, A. E.; Portoghese, P. S. Bivalent Ligands That Target $\mu$ Opioid (MOP) and Cannabinoid1 (CB1) Receptors Are Potent Analgesics Devoid of Tolerance. J. Med. Chem. 2013, 56, 5505-5513.

(40) Xie, Z.; Bhushan, R. G.; Daniels, D. J.; Portoghese, P. S. Interaction of Bivalent Ligand KDN21 with Heterodimeric Delta-Kappa Opioid Receptors in Human Embryonic Kidney 293 Cells. Mol. Pharmacol. 2005, 68, 1079-1086.

(41) Yekkirala, A. S.; Lunzer, M. M.; McCurdy, C. R.; Powers, M. D.; Kalyuzhny, A. E.; Roerig, S. C.; Portoghese, P. S. N-Naphthoyl-Beta-Naltrexamine (NNTA), a Highly Selective and Potent Activator of $\mu /$ kappa-Opioid Heteromers. Proc. Natl. Acad. Sci. U.S.A. 2011, 108, 5098-5103.

(42) Zhang, S.; Yekkirala, A.; Tang, Y.; Portoghese, P. S. A Bivalent Ligand (KMN-21) Antagonist for Mu/kappa Heterodimeric Opioid Receptors. Bioorg. Med. Chem. Lett. 2009, 19, 69786980.

(43) Zheng, Y.; Akgün, E.; Harikumar, K. G.; Hopson, J.; Powers, M. D.; Lunzer, M. M.; Miller, L. J.; Portoghese, P. S. Induced Association of Mu Opioid (MOP) and Type 2 Cholecystokinin (CCK2) 
Receptors by Novel Bivalent Ligands. J. Med. Chem. 2009, 52, 247-258.

(44) Portoghese, P. S.; Larson, D. L.; Ronsisvalle, G.; Schiller, P. W.; Nguyen, T. M.; Lemieux, C.;

Takemori, A. E. Hybrid Bivalent Ligands with Opiate and Enkephalin Pharmacophores. J. Med. Chem. 1987, 30, 1991-1994.

(45) Shafiee, A; Amanlou, M.; Farsam, H.; Dehpour, A. R.; Mir-Ershadi, F.; Mani, A. R. Synthesis and Pharmacological Activity of Thebaine-Derived Mu-Opioid Receptor Agonists. Pharm. Acta. Helv. 1999, 73, 251-254.

(46) Lewis, J. W.; Husbands, S. M. The Orvinols and Related Opioids--High Affinity Ligands with Diverse Efficacy Profiles. Curr. Pharm. Des. 2004, 10, 717-732.

(47) Bentley, K. W.; Hardy, D. G. Novel Analgesics and Molecular Rearrangements in the Morphine-Thebaine Group. I. Ketones Derived from 6,14-Endo-Ethenotetrahydrothebaine. J. Am. Chem. Soc. 1967, 89, 3267-3273.

(48) Foley, T. L.; Yasgar, A.; Garcia, C. J.; Jadhav, A.; Simeonov, A.; Burkart, M. D. Preparation of FRET Reporters to Support Chemical Probe Development. Org. Biomol. Chem. 2010, 8 (20), 46014606.

(49) Mujumdar, R. B.; Ernst, L. A; Mujumdar, S. R.; Lewis, C. J.; Waggoner, A. S. Cyanine Dye Labeling Reagents: Sulfoindocyanine Succinimidyl Esters. Bioconjug. Chem. 1993, 4, 105-111.

(50) Yuan, D.; Brown, R. G.; Hepworth, J. D.; Alexiou, M. S.; Tyman, J. H. P. The Synthesis and Fluorescence of Novel N-Substituted-1 , 8- Naphthylimides. J. Heterocycl. Chem. 2008, 45, 397-404.

(51) Gong, Y.-H.; Miomandre, F.; Meallet-Renault, R.; Badre, S.; Galmiche, L.; Tang, J.; Audebert, P.; Clavier, G. Synthesis and Physical Chemistry of S -Tetrazines: Which Ones Are Fluorescent and Why? Euro. J. Org. Chem. 2009, 2009, 6121-6128.

(52) Gong, Y.-H.; Audebert, P.; Tang, J.; Miomandre, F.; Clavier, G.; Badré, S.; Méallet-Renault, R.; Marrot, J. New Tetrazines Substituted by Heteroatoms Including the First Tetrazine Based 
Cyclophane: Synthesis and Electrochemical Properties. J. Electroanal. Chem. 2006, 592, 147-152.

(53) Gong, Y.-H.; Audebert, P.; Clavier, G.; Miomandre, F.; Tang, J.; Badré, S.; Méallet-Renault, R.; Naidus, E. Preparation and Physicochemical Studies of New Multiple Rings S-Tetrazines. New J. Chem. 2008, 32, 1235.

(54) Audebert, P.; Miomandre, F.; Clavier, G.; Vernières, M.-C.; Badré, S.; Méallet-Renault, R. Synthesis and Properties of New Tetrazines Substituted by Heteroatoms: Towards the World's Smallest Organic Fluorophores. Chem. - A Eur. J. 2005, 11, 5667-5673.

(55) Zhao, M.; Li, J.; Song, Z.; Desmond, R.; Tschaen, D. M.; Grabowski, E. J. J.; Reider, P. J. A Novel Chromium Trioxide Catalyzed Oxidation of Primary Alcohols to the Carboxylic Acids. Tetrahedron Lett. 1998, 39, 5323-5326.

(56) Valeur, E.; Bradley, M. Amide Bond Formation: Beyond the Myth of Coupling Reagents. Chem. Soc. Rev. 2009, 38, 606-631.

(57) Middleton, R. J.; Briddon, S. J.; Cordeaux, Y.; Yates, A. S.; Dale, C. L.; George, M. W.; Baker, J. G.; Hill, S. J.; Kellam, B. New Fluorescent Adenosine A1-Receptor Agonists That Allow Quantification of Ligand-Receptor Interactions in Microdomains of Single Living Cells. J. Med. Chem 2007, 50, 782-793.

(58) IUPHAR/BPS

Burprenorphine Biological

Activity

http://www.guidetopharmacology.org/GRAC/LigandDisplayForward?tab=biology\&ligandId=1670 (accessed Feb 9, 2015).

(59) Lane, J. R.; Chubukov, P.; Liu, W.; Canals, M.; Cherezov, V.; Abagyan, R.; Stevens, R. C.; Katritch, V. Structure-Based Ligand Discovery Targeting Orthosteric and Allosteric Pockets of Dopamine Receptors. Mol. Pharmacol. 2013, 84, 794-807.

(60) BODIPY® 630/650 http://tools.invitrogen.com/content/sfs/manuals/mp00143.pdf.

(61) Sulfo Cy-5 NHS ester http://www.lumiprobe.com/p/sulfo-cy5-nhs- 
ester?gclid=CNDfhLT1krkCFccTpAodCTYAwQ (accessed May 27, 2014).

(62) BODIPY 630/650 http://www.lifetechnologies.com/order/catalog/product/D10000.

(63) Stoddart, L. A; Vernall, A. J.; Denman, J. L.; Briddon, S. J.; Kellam, B.; Hill, S. J. Fragment Screening at Adenosine-a(3) Receptors in Living Cells Using a Fluorescence-Based Binding Assay. Chem. Biol. 2012, 19, 1105-1115.

(64) Elliott, J.; Smart, D.; Lambert, D. G.; Traynor, J. R. Characterisation of Mu-Opioid Receptors on SH-SY5Y Cells Using Naloxonazine and Beta-Funaltrexamine. Eur. J. Pharmacol. 1994, 268, 447450.

(65) Raynor, K.; Kong, H.; Mestek, A.; Bye, L. Characterization of the Cloned Human Mu Opioid Receptor. J. Pharmacol. Exp. Ther. 1995, 272, 423-428.

(66) Lu, J.; Jeon, E.; Lee, B.-S.; Onyuksel, H.; Wang, Z. J. Targeted Drug Delivery Crossing Cytoplasmic Membranes of Intended Cells via Ligand-Grafted Sterically Stabilized Liposomes. J. Control. Release 2006, 110, 505-513.

(67) Toll, L.; Berzetei-Gurske, I. P.; Polgar, W. E.; Brandt, S. R.; Adapa, I. D.; Rodriguez, L.; Schwartz, R. W.; Haggart, D.; O’Brien, A.; White, A.; Kennedy, J. M.; Craymer, K.; Farrington, L.; Auh, J. S. Standard Binding and Functional Assays Related to Medications Development Division Testing for Potential Cocaine and Opiate Narcotic Treatment Medications. NIDA Res. Monogr. 1998, $178,440-466$.

(68) Kobayashi, S.; Song, J.; Silvis, H. C.; Macosko, C. W.; Hillmyer, M. A. AminoFunctionalized Polyethylene for Enhancing the Adhesion between Polyolefins and Polyurethanes. Ind. Chem. Eng. Res. 2011, 50, 3274-3279.

(69) Klein, P.; Nelson, W. L.; Yao, Y. H.; Simon, E. J. Electrophilic Alpha-Methylene-GammaLactone and Isothiocyanate Opioid Ligands Related to Etorphine. J. Med. Chem. 1990, 33, 2286-2296. 
For Table of Contents Only

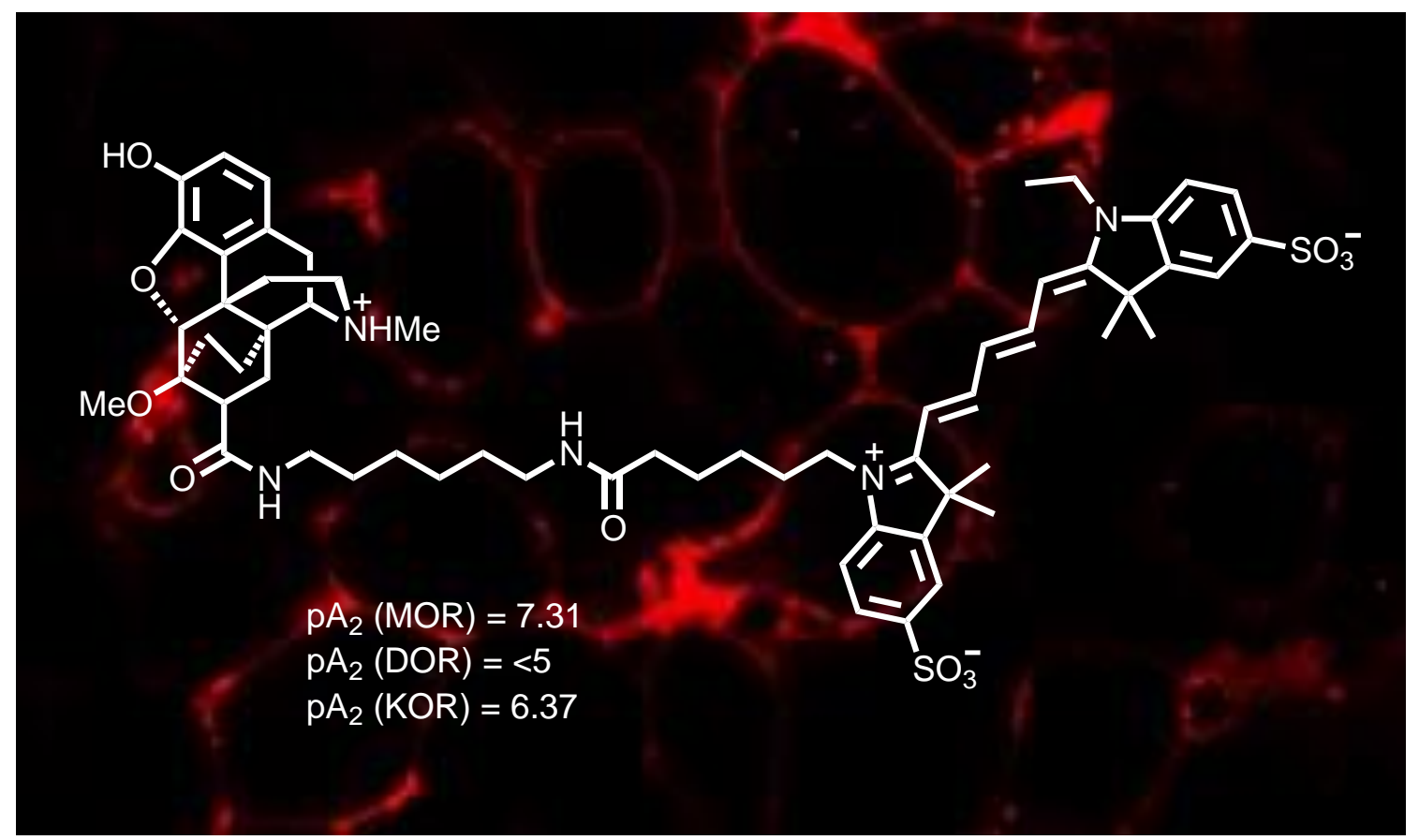

